\title{
И.В. КАРАСЕЛЬНИКОВА, В.Э.СТАДНИКОВ ОТ ОБЪЕКТА К СРЕДЕ: ПОИСК НОВЫХ ПОДХОДОВ \\ К УСТОЙЧИВОМУ РАЗВИТИЮ ИСТОРИЧЕСКИХ ТЕРРИТОРИЙ
}

Карасельникова Ирина Васильевна, эксперт Высшей школы урбанистики имени А.А. Высоковского ФГРР НИУ ВШЭ; Российская Федерация, 101000, Москва, ул. Мясницкая, д. 13, стр. 4; тел.: +7 (937) 611-75-70

E-mail: ikaraselnikova@hse.ru

Стадников Виталий Эдуардович, кандидат архитектуры, доцент Высшей школы урбанистики имени А.А. Высоковского ФГРР НИУ ВШЭ; Российская Федерация, 101000, Москва, ул. Мясницкая, д. 13, стр. 4; тел.: +7 (926) 398-63-26

E-mail: stadnikov@bk.ru

Территории исторических центров российских городов, выпавших в советское время из фокуса градостроительных политик, становятся объектом интереса частных застройщиков. Девелопмент на этих территориях ведет к утрате полезных параметрических характеристик среды, сформированных эволюционным путем: этажности, размеров землепользования, плотности застройки и пр.

Позиция публичной власти по этому вопросу сводится преимущественно к сохранению отдельных объектов культурного наследия с помощью установления охранных зон. «Историческое поселение» как инструмент, недавно появившийся в отечественной практике, позволяет индивидуализировать подход к территориям исторических центров: задать для них регламенты регулирования параметров застройки. Однако авторы статьи придерживаются той точки зрения, что данный инструментарий не является исчерпывающим, если речь идет не просто о сохранении объектов, а о запуске процесса развития территории.

С переходом к рыночной экономике собственники недвижимости, девелоперы, горожане становятся полноправными участниками городского развития со своими стимулами и интересами. Сегодня логика «сохранения» часто противопоставляется логике «развития», так как установление жесткого параметрического регулирования в краткосрочной перспективе сопряжено со снижением частных выгод каждого из игроков. Поэтому охранные меры должны дополняться комплексом мер по стимулированию, позволяющим превратить наследие в капитализируемый актив и нивелировать разницу между частными и социальными эффектами.

В первой части статьи авторы обращаются к теории городской морфологии, дающей возможность определить потенциал, которым обладает историческая среда. Во второй части дан обзор зарубежных подходов и инструментария, используемого в процессе ревитализации исторических территорий.

В третьей части авторы предлагают рассмотреть существующие российские практики с позиции горожан, девелоперов и органов власти с учетом того институционального контекста, который их окружает. В качестве иллюстрации процессов, происходящих в российских городах, выбран кейс исторического центра Самары.

Оптика нового институционализма позволяет пересмотреть подходы к оценке стимулов и эффектов, оценить вклад различных факторов в инвестиционную привлекательность территории и процесс развития в целом.

Ключевые слова: бесконфликтная реновация; историческое поселение; историческая среда; городская морфология; устойчивое развитие

Цитирование: Карасельникова И.В., Стадников В.Э. (2018) От объекта к среде: поиск новых подходов к устойчивому развитию исторических территорий // Городские исследования и практики. Т. 3. № 4. C. $108-132$.

DOI: https://doi.org/10.17323/usp342018108-132 


\section{Введение}

1 Территории исторических центров городов - это не только места концентрации объектов культурного наследия, но и сочетание исторически сформированной пространственной организации территории, морфологии застройки и системы землепользования. Исторические центры российских городов в той или иной степени сохранили застройку, сформированную до революции 1917 г., в условиях существования частной собственности, и обладают совокупностью характерных морфологических признаков [Стадников, 2010].

После революции частная собственность была отменена, и ключевым компонентом градостроительной политики стало обеспечение населения жильем. Новое жилищное строительство концентрировалось преимущественно на свободных периферийных территориях. Вплоть до 1970-х годов о ценности исторической среды речь не шла: при необходимости исторические кварталы сносились, а территория застраивалась по новым принципам. Массовое жилищное строительство, предполагающее создание как можно больших объемов жилых площадей при минимальных затратах, не было ориентировано на работу с застроенными территориями. Расселение и снос плотной исторической застройки требовали больших финансовых ресурсов $^{1}$. Это позволило историческим центрам во многих городах сохраниться [Меерович, 2008; Nutt et al., 2013]. Однако все это время сложившиеся территории не получали инвестиций в достаточном объеме и постепенно приходили в упадок.

С переходом к рыночной экономике постсоветские города возвращаются к модели, где центр является самой доступной и потому наиболее интенсивно используемой частью города [Sýkora, Bouzarovski, 2012; Hlaváček et al., 2016]. Для этой модели «центральность» является редким и потому дорогим ресурсом. В пространственной структуре постсоветских городов исторические центры часто совпадают с фактическими центрами активности или граничат с ними. Казалось бы, должен был наступить расцвет исторических центров. Однако по прошествии 30 лет можно смело утверждать, что пока этого не произошло.

С начала 1990-х годов эти территории действительно являются предметом интереса инвесторов, но в отсутствие должного регулирования девелоперы, ориентированные на максимизацию прибыли, скорее разрушают историческую среду, чем наоборот. Бум девелопмента в сочетании с советскими градостроительными нормативами, ориентированными на экстенсивное освоение с нуля, приводит к тому, что новое строительство в исторических центрах ведет к постепенной утрате исторической застройки и важных средовых характеристик [Стадников, 2019]. Одновременно с активным новым строительством происходит обветшание исторической застройки.

Долгое время государство, формируя политику работы с историческими территориями, ориентировалось на отдельные объекты, а не на среду. При этом совокупность ограничений фактически лишала собственника возможности капитализировать актив и превращала его в обременение. Причина - советский подход, не рассчитанный на участие частных агентов, на адаптацию и развитие. В советское время государство было тем единственным агентом, который планирует развитие, инвестирует и строит. Оно же распределяло население и наполняло территорию сервисами исходя из установленных нормативов. В рыночной же среде появилось множество агентов развития: органы власти, девелоперы, бизнес, горожане. Поэтому для управления развитием нужно выстраивать систему стимулов и ограничений, базирующуюся на понимании выгод этих агентов, их ресурсов и ниш, которые они могут занять.

Сегодня российское законодательство об охране объектов культурного наследия постепенно переходит от понимания исторических центров как «коллекции» отдельных памятников к осознанию ценности самой среды. Появившийся в законодательстве об охране объектов культурного наследия в 2012 г. инструмент «историческое поселение»², а также изменения Градостроительного кодекса в части особенностей установления градостроительных регламентов в исторических поселениях - это первые составляющие комплексного подхода к таким территориям. Следующий шаг - выработка мер стимулирования их развития.

1 Комментарии Н. Хрущева на эту тему можно прочитать, в частности, в «Стенограмме беседы товарища Н.С. Хрущева с руководителями Московского Совета по вопросам градостроительства. 26 мая 1962 г.».

2 Согласно Федеральному закону от 12 ноября 2012 г. N 179-Ф3 «О внесении изменений в Федеральный закон “Об объектах культурного наследия (памятниках истории и культуры) народов Российской Федерации”и Градостроительный кодекс Российской Федерации». 
Данная статья состоит из трех разделов. Первый посвящен вопросу «полезных свойств» исторической среды. Теория городской морфологии [Kropf, 2009; Oliviera, 2018] позволяет понять, как связаны отдельные параметры городской среды с характером происходящих в ней процессов [Marcus, 2017; Bobkova, 2019; Araldi, 2019]. Понимание того, как устроена эта взаимосвязь, создает предпосылки для более системной оценки последствий трансформации исторической среды.

Во втором разделе наше внимание обращено к тому, как принципы устойчивого развития и коллаборативного управления находят отражение в зарубежных подходах ревитализации исторических центров. Для этого мы представляем обзор исследований в этой области. Мы обращаемся также к исследованиям опыта стран Центральной и Восточной Европы [Sýkora, Bouzarovski, 2012; Hlaváček et al., 2016], чтобы посмотреть на проблемы, с которыми сталкиваются постсоветские города в процессе развития застроенных территорий, и на то, как меняются практики управления в условиях трансформации институтов и становления рынков.

Третий раздел посвящен прикладному исследованию исторических центров российских городов. На примере центра Самары мы разбираем ключевые проблемы, с которыми сталкиваются эти территории сегодня, их причины и препятствия для развития, существующие в современной институциональной среде. Выбор Самары в качестве кейса объясняется, вопервых, тем, что в городе сохранилось историческое ядро с характерной планировкой и застройкой, сочетанием административных и жилых функций. Во-вторых, процессы, происходящие в историческом центре города в последние десятилетия, в той или иной мере характерны для многих крупных российских городов. Это позволяет оценить последствия и эффекты распространенных сегодня практик.

В статье мы опираемся на опыт работы с историческим центром Самары, а также на исследование, проведенное в рамках выпускной квалификационной работы и посвященное подходам к оценке экономических эффектов развития исторических территорий [Карасельникова, 2018].

Методология исследования включает в себя качественный анализ документов, анализ градостроительных практик, методы пространственного анализа.

\section{Трагедия общин и внешние эффекты в исторической среде}

Дискуссии об объектах исторического наследия часто ведутся в категориях общественного блага и провалов рынка [Manson, 2005; Benesch et al., 2015]. Именно несоответствием между социальными и частными выгодами объясняется необходимость вмешательства публичной власти [Coase, 1960; Chau et al., 2018]. Например, установка требований охраны объектов наследия и введение системы льгот и поощрений для тех, кто занимается реставрацией исторических зданий. Нам представляется, что эту оптику можно применить не к отдельным объектам, а к среде в целом. Это позволит перейти к более комплексной оценке эффектов и стимулов, необходимой как для правильного понимания существующих проблем, так и для пересмотра подходов к развитию территорий.

Положительные характеристики исторической среды давно обсуждаются в работах американских авторов. Так, Джейн Джейкобс утверждает, что территории, сформированные более старыми небольшими зданиями небольшого размера, лучше новых районов жилой застройки с точки зрения их жизнеспособности, адаптивности, влияния на социально-экономические показатели [Jacobs, 1961]. Сегодня эти тезисы проверяются в эмпирических исследованиях [Older, Smaller, Better..., 2014], а полученные выводы ложатся в основу политик ревитализации и градорегулирования [Meeks, Murphy, 2016].

Далее мы обращаемся к теории городской морфологии (Urban Morphology) [Oliveira, 2018], чтобы расширить понимание полезных свойств объемно-пространственной формы исторической среды.

Морфология исторической среды и ее потенциал

Материальной составляющей «городской формы» выступают здания, земельные участки, кварталы, улично-дорожная сеть - их комбинации, размер, пропорции, связность. Нематериальной - те процессы, которые в этой среде происходят. С одной стороны, физическая среда 
формируется под воздействием пространства социального (как прошлого, так и настоящего). С другой стороны, пространственные характеристики территории могут влиять на те социальные и экономические процессы, которые на ней происходят [Kropf, 2009].

Сегодня некоторые исследователи занимаются выявлением этих взаимосвязей и эффектов. Например, лаборатория “Spatial Morphology Group” изучает, как физические параметры среды определяют набор действий, которые можно в этой среде совершить, - аффорданс среды. Их текущее исследование посвящено взаимосвязи системы межевания (характеристик земельных участков) и экономической активности [Bobkova et al., 2019]. Один из основателей лаборатории, Ларс Маркус, ввел понятие «пространственный капитал» [Marcus, 2010; 2017]. По его мнению, разные типы среды (конфигурации параметров) обладают разным потенциалом, адаптивностью к изменениям, производительностью и способностью аккумулировать внутри себя те или иные функции. Другое исследование, посвященное подходам к оценке влияния морфологии на пространственное распределение ритейла, проводится лабораторией ESPACE на примере французских городов [Araldi, 2019].

Если обобщить, набор значимых параметров включает в себя (1) связность улично-дорожной сети, (2) размер и конфигурацию кварталов, (3) процент застроенности и процент периметра квартала, занятый застройкой, (4) плотность застройки, (5) размер и конфигурацию земельных участков, (6) этажность зданий и их ориентацию относительно улиц и т.д.

Исторические территории, сформированные эволюционно, зачастую обладают тем набором пространственных характеристик, ценность которых сегодня подчеркивается теоретиками и практиками: (1) высокая доступность и связность, (2) небольшие кварталы правильной формы, (3) низкая или средняя этажность, (4) периметральное расположение застройки, (5) размеры землепользования, задаваемые парцеллярной структурой [Cтадников, 2010; Bobkova et al., 2019]. В совокупности с центральным положением территорий они создают предпосылки для наполнения функциями, стрит-ритейлом, развития малого и среднего бизнеса [Araldi, 2019; SMOG...]. Такая среда соответствует основным принципам актуальных сегодня концепций нового урбанизма [Principles...], компактного города [Ahlfedlt, Pietrostefani, 2017] и устойчивого развития.

Обращаясь к институциональной теории, можно отнести совокупность полезных характеристик среды к категории общественного блага и посмотреть на происходящие процессы через призму «трагедии общин» [Hardin, 1968]. Характеристики городской среды напрямую зависят от множества решений отдельных собственников. Ведя строительство, каждый из девелоперов преследует цель максимизации своей краткосрочной прибыли, вводя большие объемы. Один высотный дом не особенно ухудшает качества исторической среды. Его расположение в историческом центре и положительные характеристики окружающей среды лишь увеличивают стоимость квадратного метра. Но в случае, когда каждый из застройщиков возведет по дому, мы столкнемся с существенным изменением параметров среды, и в долгосрочной перспективе ее полезные свойства будут исчерпаны.

Когда агенты при принятии решений не учитывают их последствия для остальных игроков, возникают внешние эффекты - величина выгод или издержек, которые не учитываются в системе цен [Coase, 1960]. Выше мы приводили пример исключительно с девелоперами, но в пространстве города круг «игроков» значительно шире - это и горожане, и бизнес, и администрация. Отрицательные внешние эффекты включают в себя также их потери и недополученные выгоды.

Считается, что решение описанных проблем лежит в области регулирования. В городе ключевыми инструментами регулирования являются документы правового зонирования и охранные регламенты. Они специфицируют права собственников земельных участков, позволяя тем самым учесть внешние эффекты. Другой способ учета внешних эффектов - наложение санкций на тех, кто производит отрицательные экстерналии, или предоставление поддержки тем, кто производит положительные. Осознание ценности средовых характеристик критически важно для нас, если мы говорим об управлении развитием территории. Взгляд на эти ценности не только с позиции историко-архитектурной, но также с экономической и планировочной позволяет их использовать и поддерживать. 


\title{
Принципы и инструментарий развития исторических территорий
}

\author{
Устойчивое развитие и коллаборативное управление
}

Одним из базовых принципов, по которым сегодня формируется глобальная повестка развития городов, является «устойчивое развитие» [UN Habitat, 2007]. Оно базируется на рациональном использовании ресурсов, прогнозировании эффектов и оценке последствий принимаемых решений для будущих поколений. В этой логике политики, направленные на устойчивое развитие, должны иметь долгосрочный горизонт планирования и способность адаптироваться к изменениям. Сам термин «развитие»- качественная категория, отражающаяся в количественных показателях роста. Развитие посредством инноваций, инвестиций, формирования институциональной среды и инфраструктуры расширяет возможности экономических субъектов и создает условия для стабильного долгосрочного роста [Feldman, 2015].

Принципы устойчивого развития отражены в программных документах ЮНЕСКО. Наравне с сохранением объектов культурного наследия ключевая международная институция обращает внимание на проблемы развития исторических территорий [UNESCO, 2008; Ripp, Rodwell, 2016]. Постепенно происходит переход от сохранения памятников посредством бюджетных интервенций к включению в процесс более широкого круга сторон и поиску инструментов стимулирования экономической активности. На первый план выходят жители этих территорий, местный бизнес и локальные сообщества [UNESCO, 2015].

В практике работы с историческими территориями появляются термины «ревитализация», «реабилитация», «оживление». Процессы, обозначаемые этими терминами, направлены не только на изменение физической среды, но и на решение социально-экономических проблем. За долгие годы экстенсивного развития городов многие исторические центры пришли в упадок. Чтобы сделать их более привлекательными для жителей и бизнеса, в рамках городских политик предлагаются разнонаправленные меры стимулирования [EPA, 2015]. Кроме того, жесткие регламенты в сфере сохранения наследия дополняются механизмами поощрения акторов, выполняющих эти требования [Chowdhary, Jawaid, 2017].

\section{Инструментарий развития}

Существует достаточно много сравнительных исследований политик и инструментов, используемых в различных городах [Oregon Department of Land Conservation and Development, 1999; National Trust for Historic Preservation, 2002; Rich, Stoker, 2014; Conserve and Revitalise Hong Kong Heritage, 2014; EPA, 2015; Chau, 2018]. Анализируя эти работы, можно выделить следующие направления регулирования:

1) стимулирование собственников зданий заниматься их реставрацией, ремонтом и техническим обслуживанием;

2) стимулирование приспособления и использования пустующих исторических зданий (revitalization and reuse);

3) стимулирование точечного строительства (infill development), вписанного в контекст исторической среды;

4) создание предпосылок для социально-экономического развития, поддержка локального бизнеса и низовых инициатив.

В основном именно публичная сторона выступает модератором процесса преобразования территории: занимается аналитикой и стратегическим планированием, маркетингом и коммуникациями, определяет цели и приоритеты. Комплекс мер выстраивается с помощью согласованных действий отдельных ведомств и государственных программ разных уровней. Во-первых, публичная власть может использовать инструменты прямого финансирования: (1) за государственный счет создаются объекты инфраструктуры либо какие-то другие объекты, стимулирующие развитие территории; (2) для создания инфраструктуры и ревитализации объектов также применяется механизм публично-частного партнерства; (3) различным стейкхолдерам - собственникам и их объединениям, некоммерческим организациям, компаниям-резидентам предоставляются целевые субсидии и гранты. Во-вторых, используются инструменты косвенного стимулирования: (1) гибкое смягчение нормативов и система бонусов в зонировании; (2) налоговые льготы по имущественным налогам, налогам на прибыль 
и добавленную стоимость - снижение процентных ставок и их территориальная дифференциация, налоговые каникулы и вычеты; (3) специальные условия кредитования и снижение процентных ставок за счет государственных гарантий; (4) развитие институциональной среды и финансовой инфраструктуры; (5) информационная и техническая поддержка, центры компетенций.

Финансирование расходов на развитие происходит как за счет собственных доходов муниципалитета, так и за счет адресных программ вышестоящих бюджетов (это зависит от уровня централизации бюджетной системы). Также для привлечения средств на инвестиционные нужды используется долговое финансирование [Kim, 2016] - выпуск муниципальных ценных бумаг.

\section{Институциональная среда}

Принципы и подходы, описанные в этом разделе, сформировались и получили широкое распространение в странах с развитыми рыночными системами и неолиберальным подходом к государственному управлению. В этих странах активно используются практики коллаборативного управления - частные игроки воспринимаются государством как партнеры. Кроме того, эти страны имеют сформированные эволюционным путем институциональные системы.

В институциональной экономике принято связывать уровень развития с состоянием институциональной среды и развитостью отдельных институтов [North, 1973; Alchian, Demsetz, 1973; Acemoglu, Robinson, 2012]. Под институтами обычно понимают «правила игры, включающие формальные и неформальные ограничения, а также принуждение к выполнению тех и других» [Hopm, 1997; Ostrom, 2005]. Среди основных функций институтов выделяют снижение неопределенности, обеспечение безопасности и стабильности, структурирование выбора, сокращение трансакционных издержек [Hopm, 1997]. Иными словами, институты специфицируют права собственности. Так, например, документы правового зонирования, являясь формальным институтом, определяют набор сценариев использования земельных участков и объем прав собственников. Совокупность разноуровневых формальных и неформальных правил составляет институциональную среду. Неразвитость институциональной среды - противоречивость нормативно-правовой базы, неработающая судебная система, конфликт между формальными и неформальными институтами, - ведет к размыванию прав собственности и снижению инвестиционной активности.

С одной стороны, города существуют в сложившейся институциональной среде: сложившейся прежде и на более высоких уровнях управления. С другой стороны, городская власть формирует институциональную среду посредством управления и регулирования.

Страны с социалистическим прошлым обрели свободные рынки и новые институты в одночасье. Фактически новые формальные правила были привнесены в эти страны извне, а не сформированы эволюционным путем - в процессе адаптации к существующей институциональной среде такие институты порой меняли свое содержание [Полтерович, 2001; Но, 2019 ]. Исследователи описывают общие проблемы городского развития в постсоциалистических странах [Меерович, 2012; Sýkora, Bouzarovski, 2012; Nutt, 2013]. В условиях несформировавшихся рыночных институтов и нерегулируемого капитализма центры городов становятся предметом интереса девелоперов. Это часто вызывает недовольство жителей, но у них нет сформировавшихся моделей выражения этого недовольства. Несмотря на появление формально определенных прав собственности, жители не становятся одномоментно агентами, имеющими политический вес. При этом у власти нет инструментов работы с мнением горожан [Hlaváček et al., 2016]. А в силу несформированности финансовых рынков и инструментов, у других субъектов, помимо крупных инвесторов, нет возможности реализовать альтернативные модели работы с городскими территориями. Перечисленные проблемы встречаются в разных странах и разных городах, а власти по-разному на них реагируют: стремятся преодолеть или, наоборот, используют в своих интересах.

Прежде чем начинать разговор про инструменты развития исторических центров в российских городах, необходимо разобраться в особенностях отечественного институционального контекста и в причинах тех негативных тенденций, которые мы сегодня наблюдаем. 


\section{Исторические центры российских городов: проблемы развития и стимулы стейкхолдеров}

Сегодня в исторических центрах существует ряд видимых проблем: обветшание зданий, рост незанятых площадей, тотальный снос рядовой застройки, несоразмерное масштабу исторических зданий новое строительство. В причинах этих проблем мы попробуем разобраться далее на примере Самары. Также мы обозначим ряд институциональных и социально-экономических особенностей, препятствующих устойчивому развитию.

Снос рядовой застройки и переселение жителей за пределы центра

Важную роль играет само отношение к территориям с исторической застройкой, возникшее в общественном дискурсе в 1990-2000-х годах и существующее до сих пор. Исторические здания, не ставшие объектами культурного наследия, но имеющие градостроительную и историческую ценность, преимущественно жилые, сегодня воспринимаются как «трущобы» и «гнилушки» ${ }^{3}$, жилье низкого качества. Зачастую они действительно не обеспечены водоснабжением, теплоснабжением и канализацией, а капитальный ремонт долгое время обходил их стороной. В советское время эти дома были преобразованы в многоквартирные. Сегодня площадь этих квартир не удовлетворяет нормативам обеспеченности населения жильем, которые декларируются на федеральном уровне в качестве целевых

Историческая застройка попадает в программы расселения ветхого и аварийного жилья. Под предлогом улучшения жилищных условий жителей центральных районов переселяют преимущественно на периферию, в новые микрорайоны ${ }^{5}$. Под расселение попадают порой не только отдельные дома, но и целые кварталы. А освободившееся место застраивается по принципу комплексного освоения территорий.

Яркий пример - программа расселения ветхого и аварийного жилья, запущенная в Казани в преддверии тысячелетия города (1996-2004 гг.). Всего в рамках программы расселили 5 тыс. домов (33 тыс. семей), половина из которых находились на территории исторического центра. Под снос попадали целые кварталы, а сохранялись лишь отдельные здания - объекты культурного наследия ${ }^{6}$ Центр города лишился своей жилой функции, и характер его использования изменился. На месте снесенных кварталов строилось либо элитное жилье, либо административно-деловые здания. Расселенные объекты культурного наследия долгое время пустовали ремонтировались лишь фасады, выходящие на главные улицы. Сегодня эти здания постепенно заполняются функциями.

Результаты такой политики можно проследить по данным [Реформы ЖКХ] (рис. 1): многоквартирные исторические дома как тип застройки практически исчезли из центров не только Казани, но и других городов-миллионников. Деревянная и каменная многоквартирная жилая застройка, появившаяся до 1930-х годов, преимущественно сохранилась в Самаре, Ростове-наДону и Нижнем Новгороде.

В Самаре сегодня порядка 17\% многоквартирных домов - это историческая застройка. На puc. 2 видно, что на территории исторического центра (700 га) сохранились полноценные жилые кварталы. Функциональная смешанность - выгодная отличительная черта самарского центра и потенциал для его сбалансированного развития. Кроме того, на этой территории сегодня активно ведется жилищное строительство: преимущественно это большие по площади многоэтажные дома.

3 Такие обороты часто встречаюся в СМИ, в прямой речи глав регионов и городов, например: Губернатор предстал в откровении. Николай Меркушкин обратился с посланием к депутатам и жителям // Коммерсанть (Самара). 2013. 27 декабря. № 240 <https://www.kommersant.ru/doc/2377710>.

4 Согласно Распоряжению Правительства РФ от 17 ноября 2008 г. N 1662-р (ред. от 28.09.2018) «О Концепции долгосрочного социально-экономического развития Российской Федерации на период до 2020 года».

5 См., например: Расселение пойдет активнее // Самарская газета. 2013 <https://sgpress.ru/news/31864>; Реновация по-кавказски: жители Нальчика не хотят нового жилья // Кавказский узел. 2019 <https://www. kavkaz-uzel.eu/articles/Caucasian_Renovation_Nalchik_Residents_Do_Not_Want_New_Apartments/>.

6 Согласно Решению казанского Совета народных депутатов от 30 октября 1996 г. N 1-5 «О Программе ликвидации ветхого жилого фонда и реконструкции кварталов ветхого жилья в г. Казани». 

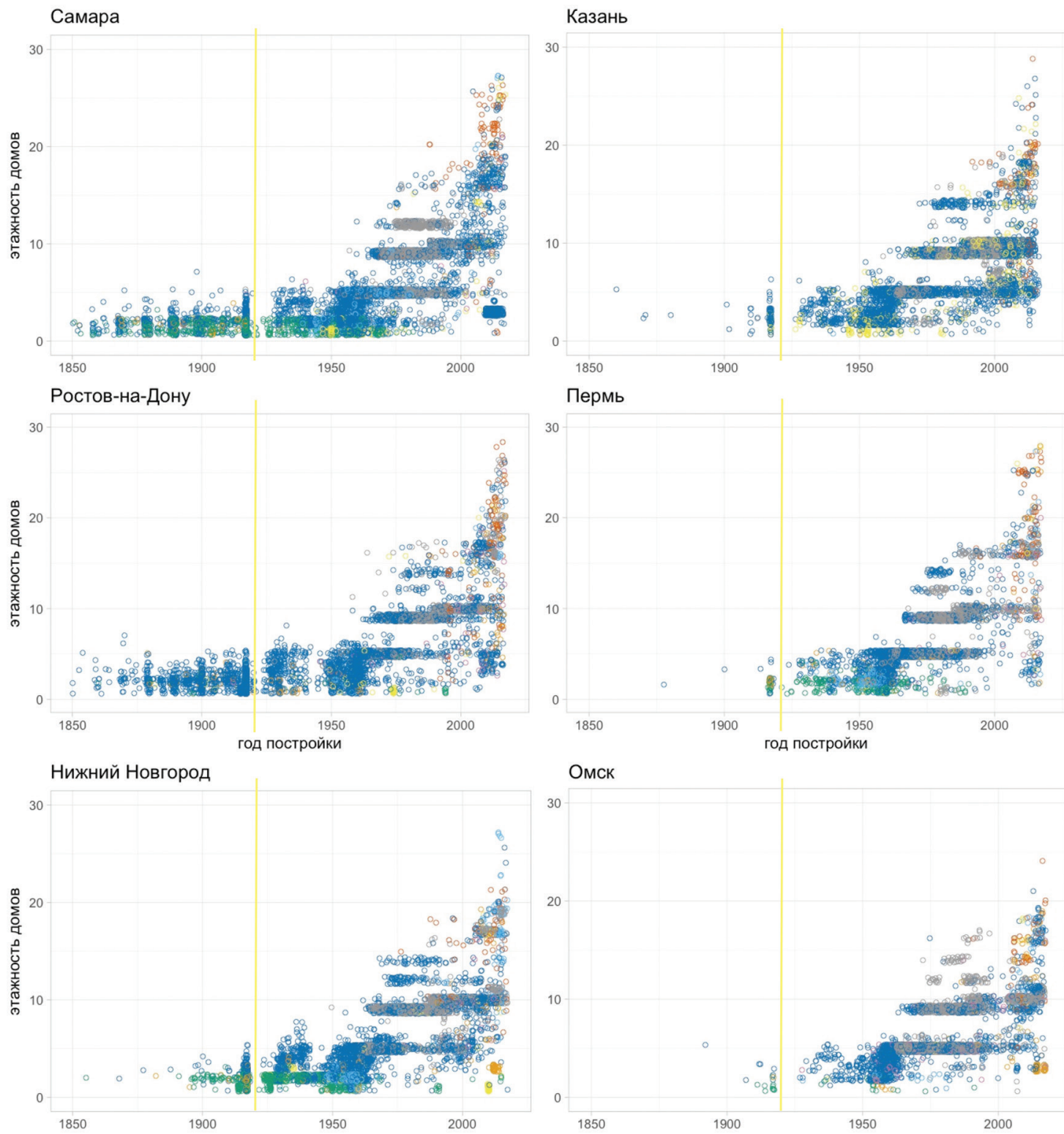

Омск
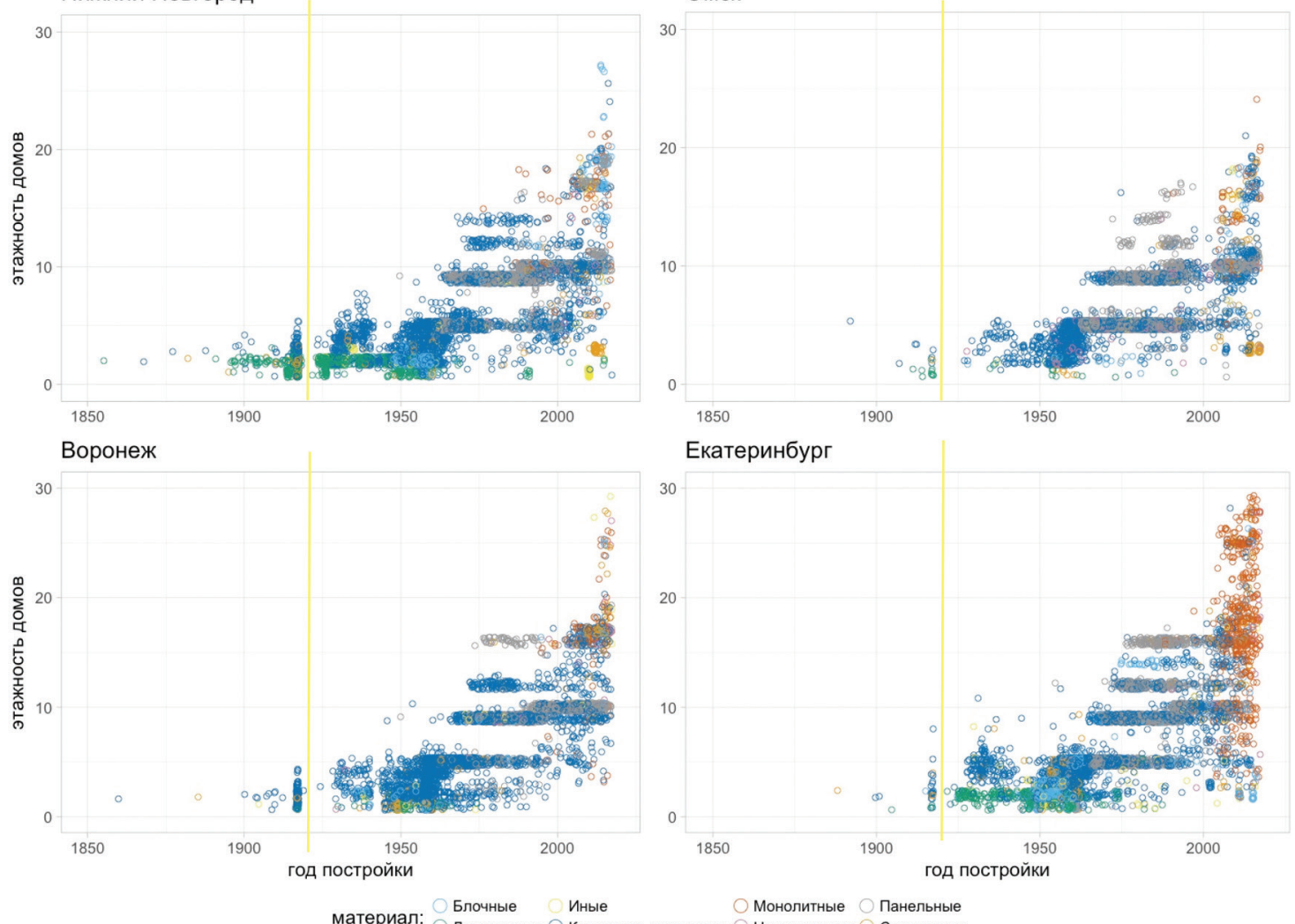

Рис. 1. Классификация многоквартирных жилых домов по этажности, типу и году постройки

Источник: [Реформа ЖКХ], аналитика авторов статьи. 


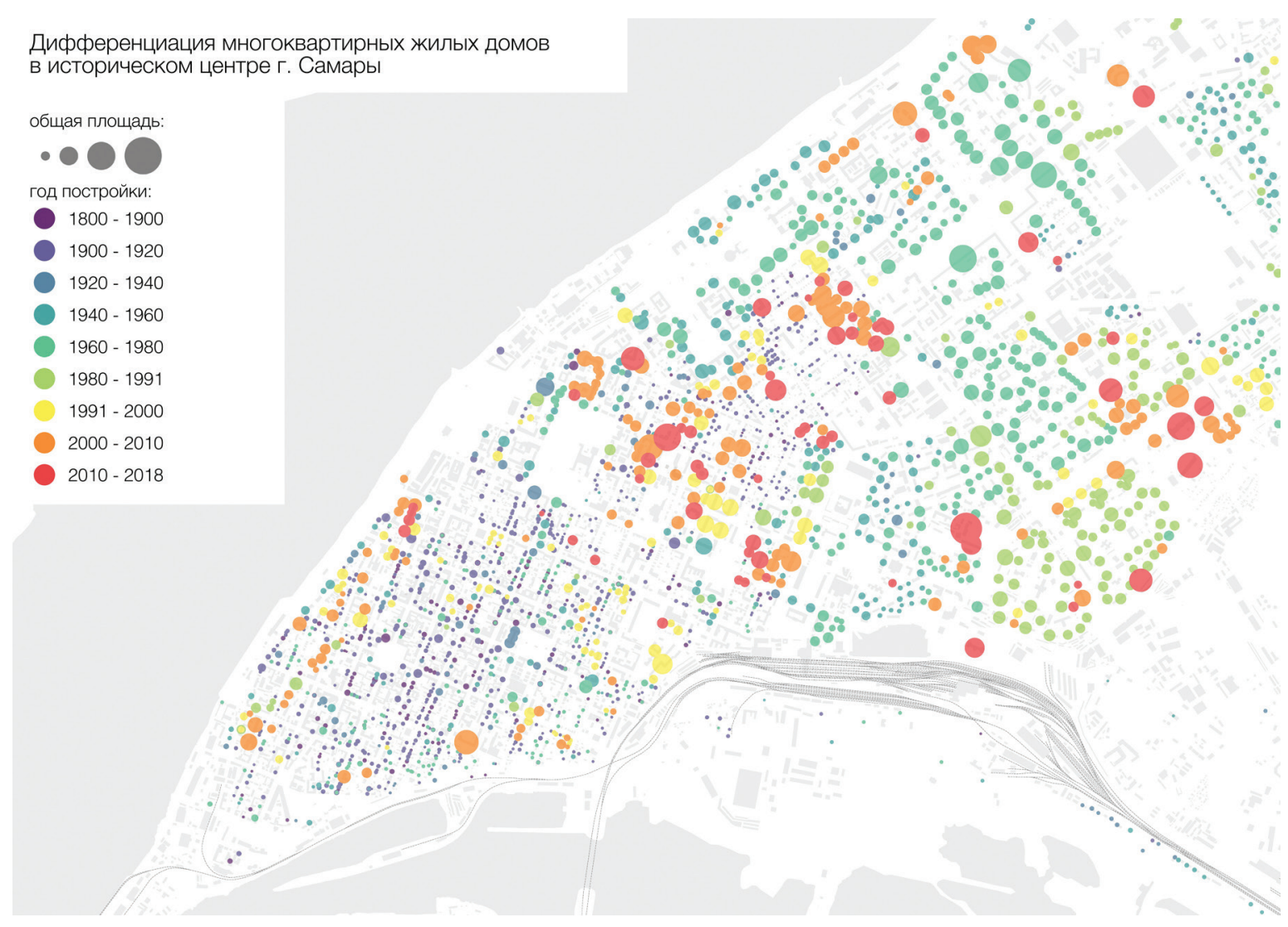

Данные картографической основы: ๑ Участники проекта OpenStreetMap

Рис. 2. Многоквартирные жилые дома в историческом центре Самары

Источник: [Реформа ЖКХ], аналитика авторов статьи.

Новая застройка и разрушение исторической среды

Исторический центр Самары обладает теми объемно-пространственными характеристиками среды, о которых шла речь в первом разделе: на большей части территории сохранилась историческая планировка, парцелляция и размерность застройки [Стадников, 2010; Институт Города Самара, 2016]. Однако текущие практики девелопмента игнорируют этот потенциал и ведут к постепенной его утрате.

Новая застройка в центре осуществляется в основном на месте снесенной малоэтажной застройки, в кварталах с низкой плотностью и небольшим числом объектов культурного наследия. В отсутствие инвентаризации и объективной оценки физического износа жилой застройки механизм признания зданий аварийными превратился в инструмент манипуляций: расселению часто подлежат именно те дома, которые располагаются на интересующих девелопера участках.

Если муниципалитет отстраняется и не включает тот или иной дом в программу расселения, жители остаются один на один с застройщиком. После недолгих переговоров к тем, кто не готов добровольно согласиться на предложенные условия, применяются различные механизмы принуждения. Крайний случай - поджоги. Карта распределения пожаров с временным лагом в год-полтора воспроизводится на карте расположения нового жилищного строительства [Карта пожаров...] ${ }^{7}$.

7 Карта пожаров в Самаре, «Самара для людей» <https://www.google.com/maps/d/u/0/viewer?hl=ru\&mid=1s6 EuKA9MbgMOFSvRMvH_GEXsZf8\&ll=53.17875982217774\%2C50.12701024577427\&z=13>. 


\section{Стимулы девелоперов}

Таким образом, частные девелоперы являются ключевыми игроками на исторических территориях, в том числе и в Самаре. Типовые проекты массового многоквартирного жилья повышенной этажности рассчитаны на короткий срок окупаемости, отработанную финансовую и управленческую модель. Территории исторических центров привлекают девелоперов, поскольку стоимость жилой недвижимости в них часто превышает среднегородской уровень. Это видно на рис. 3, где пунктиром показана усредненная по городу стоимость квадратного метра, а сплошной линией - стоимость на территориях с преобладанием исторической застройки.

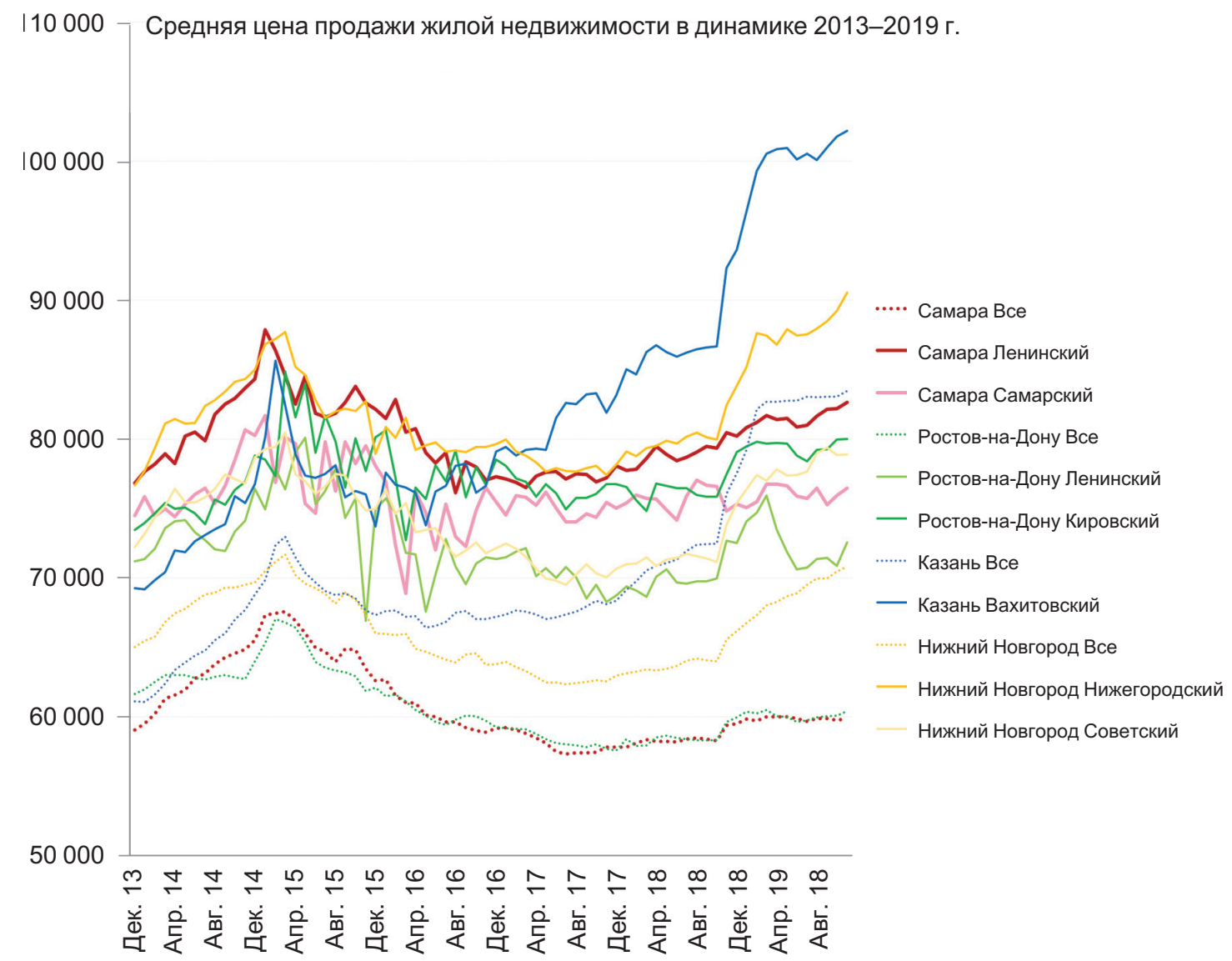

Рис. 3. Цена продажи жилой недвижимости ${ }^{8}$

Источник: подготовлено авторами на основе данных сайта о недвижимости России Domofond.ru <https:// www.domofond.ru/tseny-na-nedvizhimost>.

При этом проекты развития с сохранением параметров исторической среды девелоперу невыгодны. Долгосрочный характер окупаемости таких проектов, их высокая капиталоемкость, значительное число сторон, прямо и косвенно в них участвующих, сложность и запутанность существующих регламентов - эти характеристики значительно увеличивают рисковую составляющую в ставке дохода на капитал [Chau et al., 2018; Amirtahmasebi et al., 2016]. В сегодняшних условиях - при возможности внесения изменений в Правила землепользования и застройки, корректировки зон охраны объектов культурного наследия - застройщик старается компенсировать издержки за счет повышения этажности и отказывается от работы в существующих

8 Для сравнения представлены города-миллионники, на территории которых сохранилось историческое ядро с характерной планировкой и застройкой. 
параметрах исторической среды. Увеличение этажности в комбинации с действующими нормативами препятствует сохранению всех других морфологических свойств среды [Институт Города Самара, 2016]. Помимо этого, в российской практике муниципалитеты возлагают на девелопера создание коммунальной и социальной инфраструктуры [Строительство с обременением, 2017; Решение Пермской городской думы от 27.08.2019 № 171], что делает финансовую модель проектов еще менее привлекательной.

Самарские проекты, предполагавшие в большей или меньшей степени гуманное отношение к исторической среде, - проект «бесконфликтной реновации» 79-го квартала [Метод бесконфликтной..., 2014] и проект «5 кварталов» [Пять кварталов Самары..., 2014] - показывают, что развитие в параметрах исторической среды в нынешних условиях не обеспечивает инвесторам требуемой окупаемости'.

Есть основания полагать, что с введением понятных детализированных регламентов на территории исторического центра, появлением последовательной политики муниципалитета в сфере регулирования и отказом от бессистемного внесения изменений в документы правового зонирования на рынке появится некоторая определенность, а у застройщиков возникнут стимулы работать в новом для них формате. Однако нужно понимать, что появление ограничений в историческом центре города при отсутствии регулирования в остальных его частях в краткосрочной перспективе ставит центр в невыгодное положение и может способствовать оттоку строительной активности [Гудзь, Косолапов, Карасельникова, 2020].

Приводимые нами во втором разделе меры по стимулированию наполняющей застройки исторических центров в США и Европе осуществляются в условиях гораздо более развитого рынка недвижимости и разнообразия форматов девелопмента. В сегодняшней России инвесторы, привыкшие к крупным строительным проектам, не готовы работать с мелким масштабом проектов в исторической среде. Увеличение доли крупных инвесторов и стремительно растущая монополизация рынка жилья на федеральном и региональном уровне усугубляют эти тенденции. Так, в Самарской области сегодня 58\% рынка контролирует десятка крупнейших инвесторов [Мониторинг Института развития..., 2018]. И без того слабо развитый сегмент микродевелопмента постепенно уходит с такого рынка, сталкиваясь со все новыми трудностями [Разница в весе, 2019].

\section{Право собственности на землю и стимулы горожан}

Важной характеристикой российской институциональной среды является отношение к праву собственности на недвижимость. На протяжении 70 лет советской власти право частной собственности отрицалось как таковое, а с переходом к рыночным отношениям началась стремительная приватизация. В первую очередь она коснулась жилых квартир, позднее земельных участков. В результате такого развития событий до сих пор значительные части городских территорий остаются неразмежеванными ${ }^{10}$. Это не позволяет собственникам жилья использовать землю как инвестиционный ресурс [Alchian, Demsetz, 1973; Де Como, 2001], а власти - выстраивать эффективную налоговую политику. Сам процесс межевания сложный и дорогой, у жителей не всегда есть возможность провести его за свой счет. Кроме того, даже наличие легального титула собственности не поощряет собственников к каким-либо действиям, а окружающая институциональная среда скорее их дестимулирует. В особенности собственников земельных участков под многоквартирными домами - они освобождены от уплаты налога на землю, а программы расселения ветхого и аварийного жилья, развития застроенных территорий с их форматами перераспределения имущественных прав создают квазирыночный оборот земельных участков.

На территориях исторических центров эти процессы проявляются максимально ярко. Право собственности в отношении недвижимости находится в состоянии неопределенности, что обусловлено ожиданием сноса домов в ближайшее время. Это коллективное ожидание: с одной стороны, жители ничего не предпринимают, ожидая, что их переселят в новое жилье. С другой, муниципалитет не инвестирует в территорию, развитие коммунальной инфраструк-

9 На основе анализа финансовых моделей проектов и серии интервью с их разработчиками. 10 Аналитика авторов, источник - Росреестр. 
туры, ремонт, ожидая, что придет инвестор с проектом развития территории и возьмет на себя затраты по сносу и обеспечению новой застройки всей необходимой инфраструктурой.

В совокупности состояние домов, негативное восприятие исторических территорий и специфическое понимание отношений собственности приводит к конфликтам жителей и защитников культурного наследия. Существует разрыв между пониманием значимости наследия узким кругом специалистов и активистов и желанием собственников улучшить свои жилищные условия. Один из последних примеров подобного конфликта - процесс сноса Арских казарм в Казани [Хронология..., 2019].

Во втором разделе мы обращали внимание на то, что в постсоциалистических странах есть проблемы в выстраивании коммуникации между публичной властью и жителями. Российские города не исключение. Ни планировщики, ни администрация не знают практически ничего про жителей исторических центров, равно как и про других горожан. Российская статистика в основном агрегирована в масштабе города или района. Это большие гетерогенные территории, усредненные показатели по которым едва ли говорят что-то об отдельных кварталах и домах. О жителях можно судить по косвенным признакам, доступным в формате пространственных данных. Этого явно недостаточно для разработки детальной стратегии развития исторического центра.

Сегодня возникают общественные инициативы, косвенно или напрямую связанные с развитием исторической среды. Один из таких примеров - фестиваль восстановления исторической среды «Том Сойер Фест», зародившийся в Самаре. Тема низовых инициатив, взаимодействия с ними, партисипаторных практик - это то, без чего нельзя обойтись в процессе «оживления» исторических территорий. Сегодня такие инициативы появляются скорее вопреки действиям публичной власти. В российских регионах появляются различные инициативы публичной власти по вовлечению горожан: от партисипаторного проектирования общественных пространств до партисипаторного (инициативного) бюджетирования, но они в меньшей степени касаются вопросов территориального развития и исторических центров [Карасельникова, 2017]. Российские архитекторы и исследователи отмечают необходимость внедрения партисипаторных практик в управление развитием исторических территорий, однако публичная власть пока к этому не готова [Лащенко, Репина, Грозовский, 2018].

Право собственности на землю и изменения среды

Если посмотреть на рuс. 4-6, становится понятной ключевая проблема существующего межевания в историческом центре Самары - несоответствие формальных границ земельных участков фактическим границам землепользования. Также заметно, что на существенной части центра сохранились исторические размер и конфигурация домовладений. Другая часть трансформировалась: на месте парцелл образовались крупные участки.

Такие земельные участки формируются по следующей схеме: отсутствие межевания или межевание «под отмостку» позволяет муниципалитету передавать неразграниченные территории внутри кварталов в долгосрочную аренду под жилищное строительство. На рис. 7 показан механизм освоения нескольких кварталов на периферии исторического центра Самары.

Такие изменения конфигурации земельных участков приводят к исчезновению гранулярности исторической среды - свойства, которое обеспечивает разнообразие, функциональную смешанность и адаптивность. На объединенных земельных участках появляются крупные жилые здания, первые этажи которых единым лотом сдаются в аренду крупным арендаторам. Кроме того, нарушается непрерывность фронта застройки, внутри квартала появляются плоскостные парковки (рис. 8).

\section{Политики и стимулы публичной власти}

Сегодня политики власти в сфере сохранения наследия слабо увязаны со стратегическим планированием и градорегулированием. Так, например, в Генеральном плане Самары есть раздел, посвященный культурному наследию, но содержательно он не соответствует современному законодательству. В нем определена Щентральная историческая планировочная 


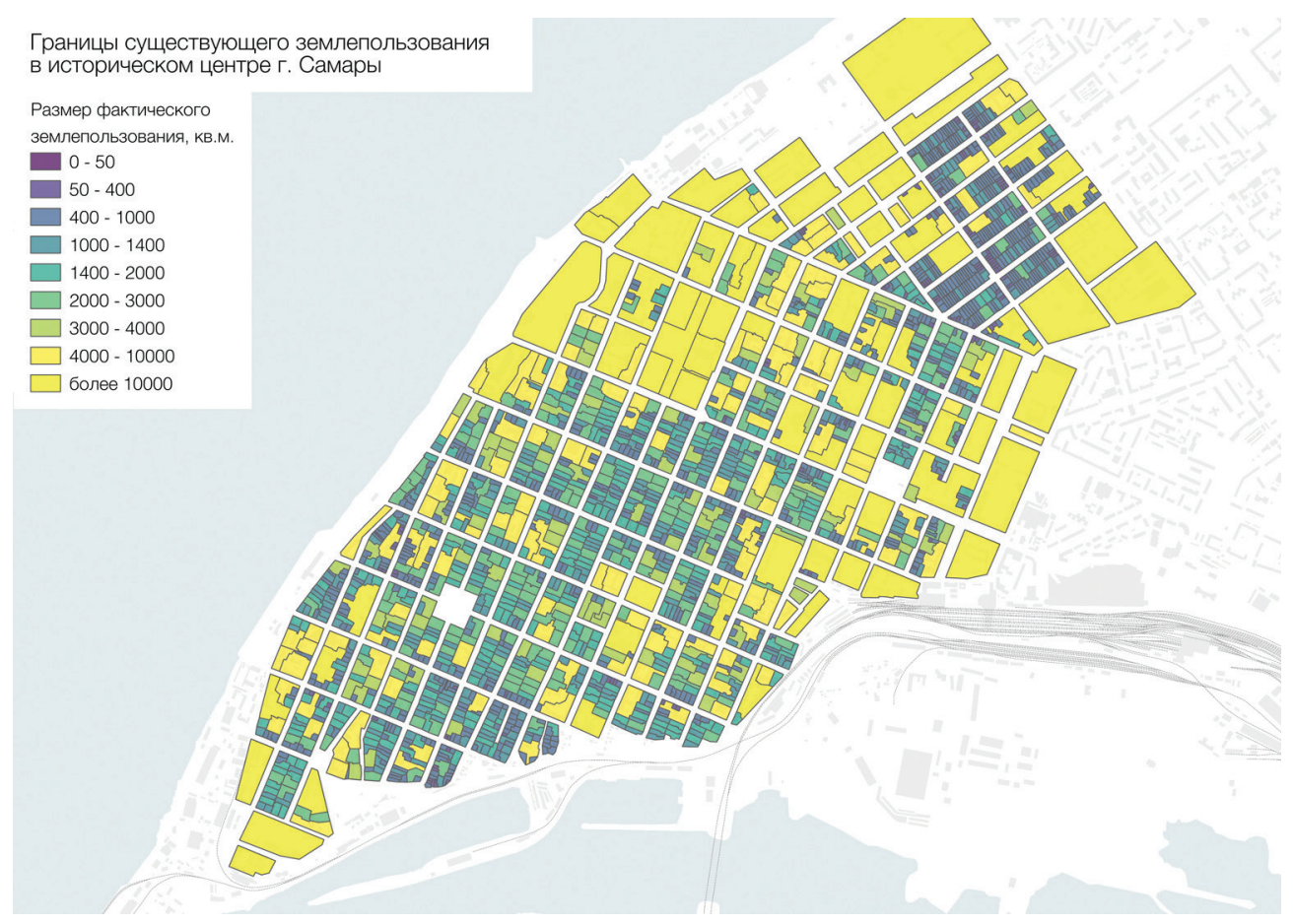

Данные картографической основы: ๔ Участники проекта OpenStreetMap

Рис. 4. Границы и размер фактического землепользования в историческом центре Самары, 2019 г.

Источник: составлено авторами на основе Рабочих материалов в рамках разработки проекта исторического поселения г. Самары.

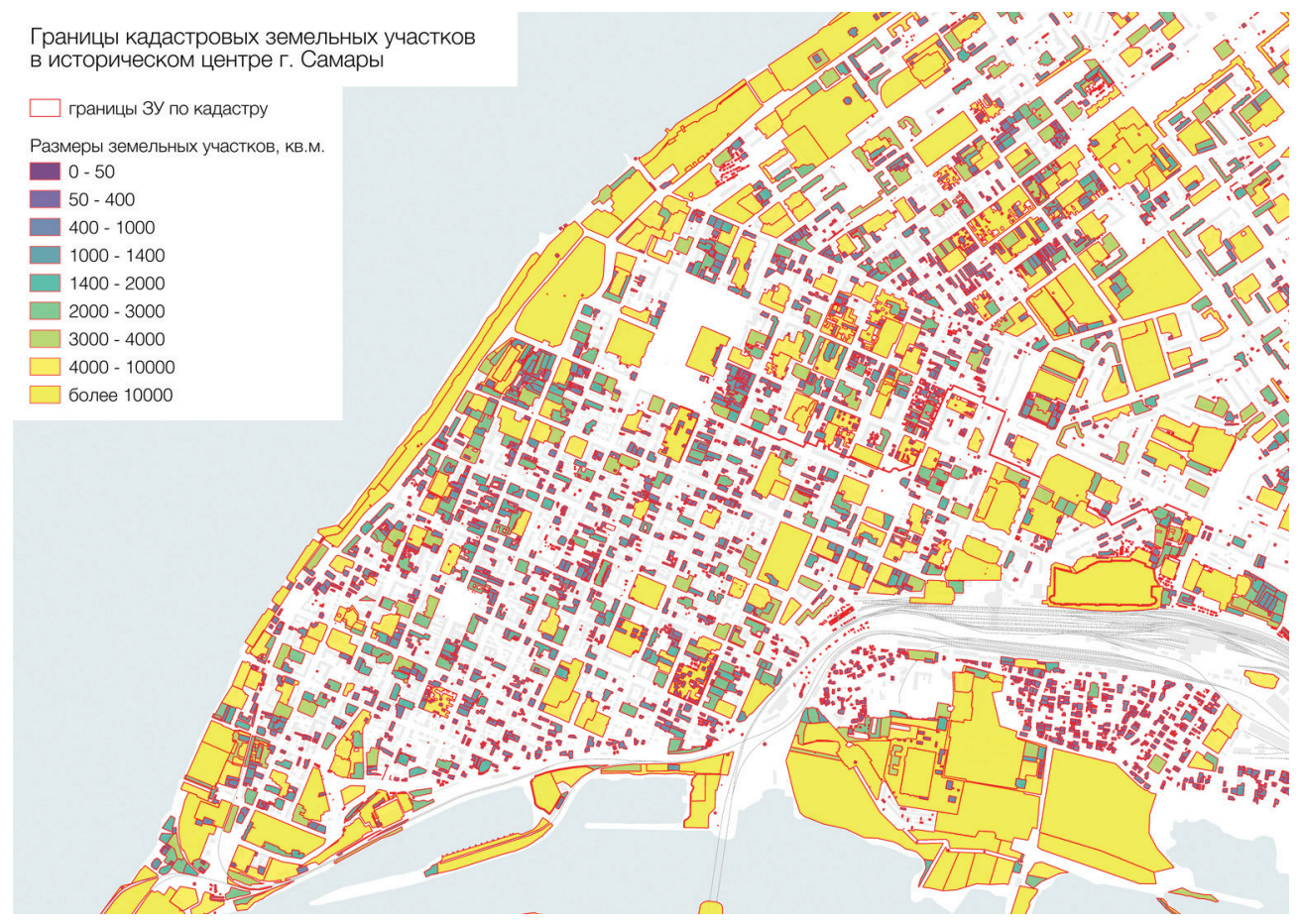

Данные картографической основы: ๔ Участники проекта OpenStreetMap

Рис. 5. Границы и размер кадастровых участков в историческом центре Самары, 2019 г.

Источник: составлено авторами на основе данных Росреестра. 


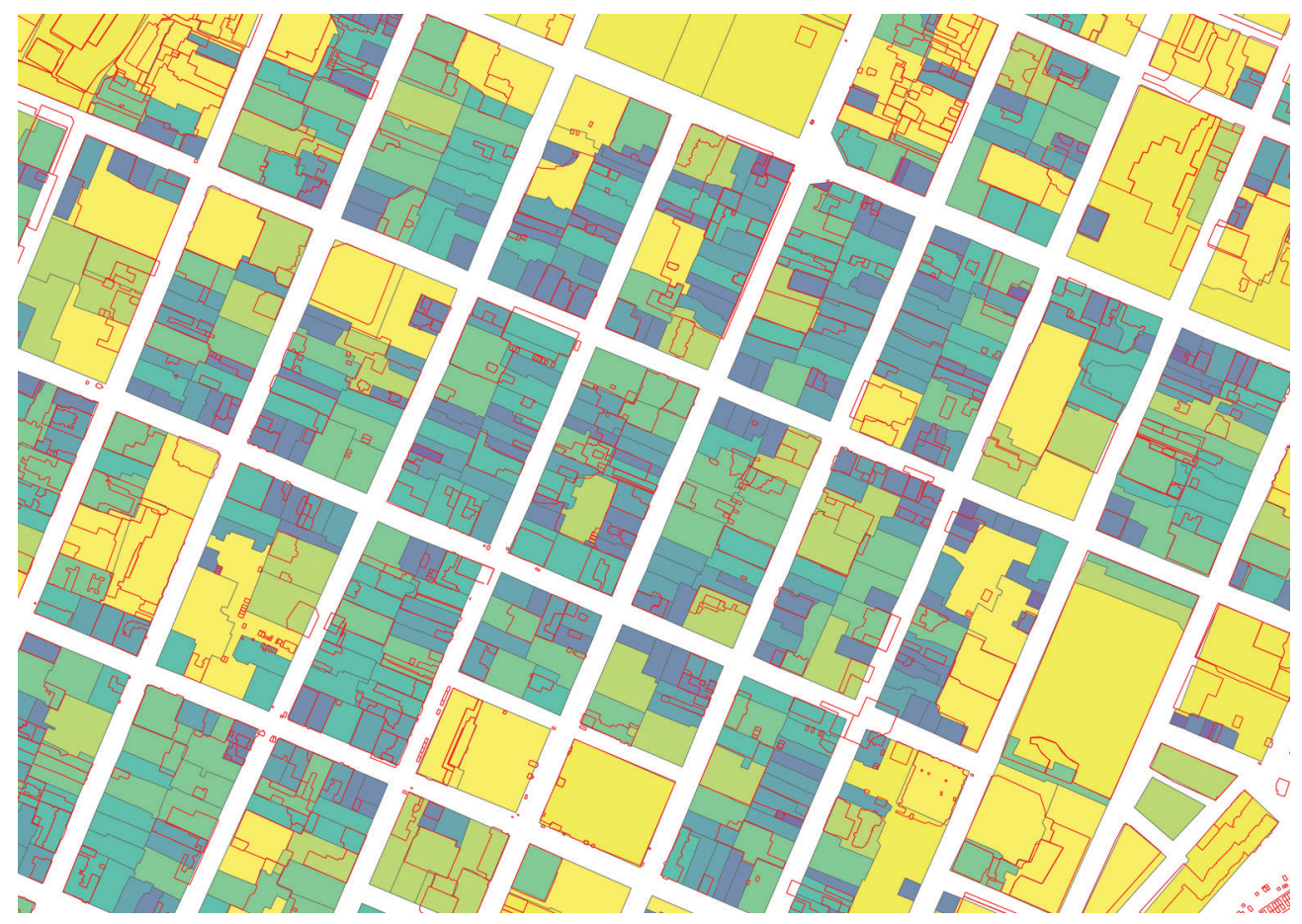

Данные картографической основы: ๔ Участники проекта OpenStreetMap

Рис. 6. Сопоставление границ землепользования с формальными границами земельных участков (фрагмент)

зона» ${ }^{11}$ - несуществующее в законодательстве понятие. В «Правилах землепользования и застройки» закреплены особые режимы использования для территории исторического центра $^{12}$, но они также никак не увязаны ни с «Генеральным планом», ни с охранными зонами объектов культурного наследия, что приводит к неопределенности сценариев использования земельных участков, а также к противоречивости политик муниципалитета. Это происходит, несмотря на то, что формально «осуществление градостроительной деятельности с соблюдением требований сохранения объектов культурного наследия» является одним из принципов градостроительного законодательства ${ }^{13}$. Интеграция политики сохранения объектов культурного наследия в политику пространственного развития территорий с исторической застройкой - суть этого принципа. Сегодня появился такой инструмент, как «историческое поселение», позволяющий состыковать требования охраны исторической среды и регламенты ПЗЗ. Ряд городов, получивших статус исторического поселения, в том числе Самара и Казань, находятся на этапе разработки требований к градостроительным регламентам.

Если говорить о стимулах органов власти, следует понимать, что они напрямую связаны с полномочиями, установленными законодательно. А полномочия, в свою очередь, - с бюджетными ресурсами. Централизация бюджетной системы и постоянное увеличение фискального дисбаланса бюджетов разных уровней отражаются на особенностях местного самоуправления и стратегического планирования в целом. Муниципальные власти стабильно лишаются полномочий, доходных источников наполнения бюджета. В муниципальный бюджет перечисляются только поступления по местным налогам (земельный налог, налог на имущество физических лиц и торговый сбор), специальным налоговым режимам (ЕНВД, ЕСХН, патентная система), а также $15 \%$ от совокупного объема налога на доходы физических лиц [Бюджетный кодекс...,

11 Согласно решению Думы городского округа Самара от 20 марта 2008 г. № 539 «Об утверждении Генерального плана городского округа Самара» (с изменениями на 5 декабря 2019 г.), ст. 4.2 .5 <http://docs. cntd.ru/document/945019653>.

12 Согласно решению Думы городского округа Самара от 26 апреля 2001 г. № 61 «Об утверждении Правил застройки и землепользования в городе Самаре» (с изменениями на 19 декабря 2019 г.) <http://docs.cntd. $\mathrm{ru} /$ document/945005955>.

13 В соответствии со ст. 2 Градостроительного кодекса Российской Федерации от 29 декабря 2004 г. N 190-Ф3 (ред. от 27.12.2019). 

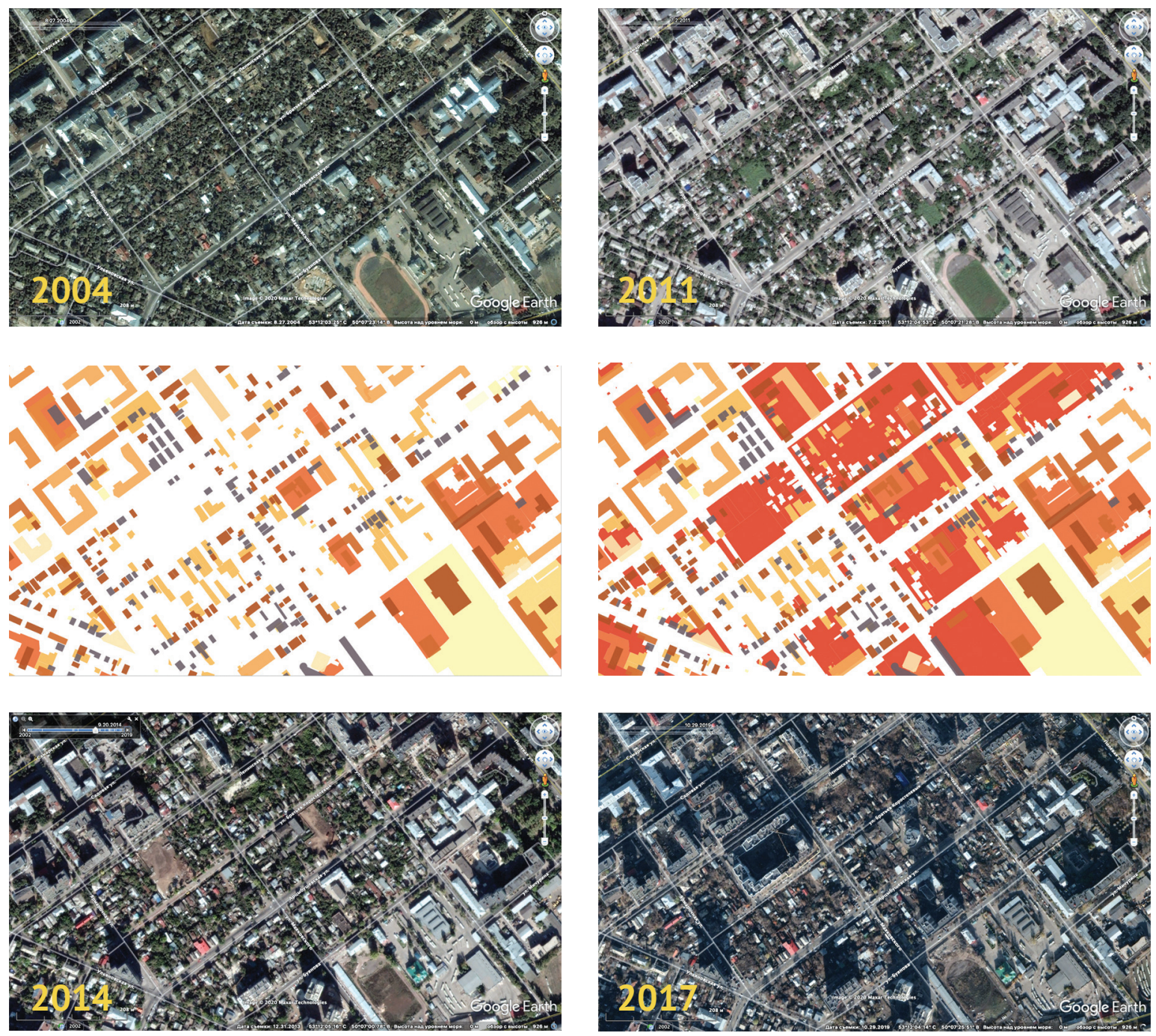

Данные картографической основы: () Участники проекта OpenStreetMap; @ Google

\section{Рис. 7. Пример выделения участков под застройку на неразграниченной территории внутри исторического квартала в Самаре}

Источник: составлено авторами на основе данных Росреестра.

cm. 61.2]. Проблемы с межеванием земельных участков и отмена налога на землю под многоквартирными домами не позволяют муниципалитету выстраивать налоговую политику. В среднем около 50\% доходов муниципального бюджета составляют трансферты, перечисляемые из вышестоящих бюджетов и имеющие в основном целевое назначение [КБ «Стрелка»..., 2017].

Ориентация местных властей на получение безвозмездных поступлений «сверху» лишает их стимулов повышать эффективность использования внутренних ресурсов: совершенствовать фискальную политику, увеличивать собственные доходы, привлекать заемные средства, инвестиции, оценивать эффекты от принимаемых решений. В то же время при наличии стимулов проработанная структура источников финансирования (средств бюджетов разных уровней, целевых программ, инвестиций в рамках государственно-частного партнерства) позволяет аккумулировать на одной территории значительные финансовые ресурсы.

Следует отметить, что региональная власть сегодня является ключевым актором городских политик - значительное число инициатив в области городского развития и управления исходит именно от нее. Таким путем она стремится достичь высоких показателей оценки эффективности [Указ Президента..., 2019]. 

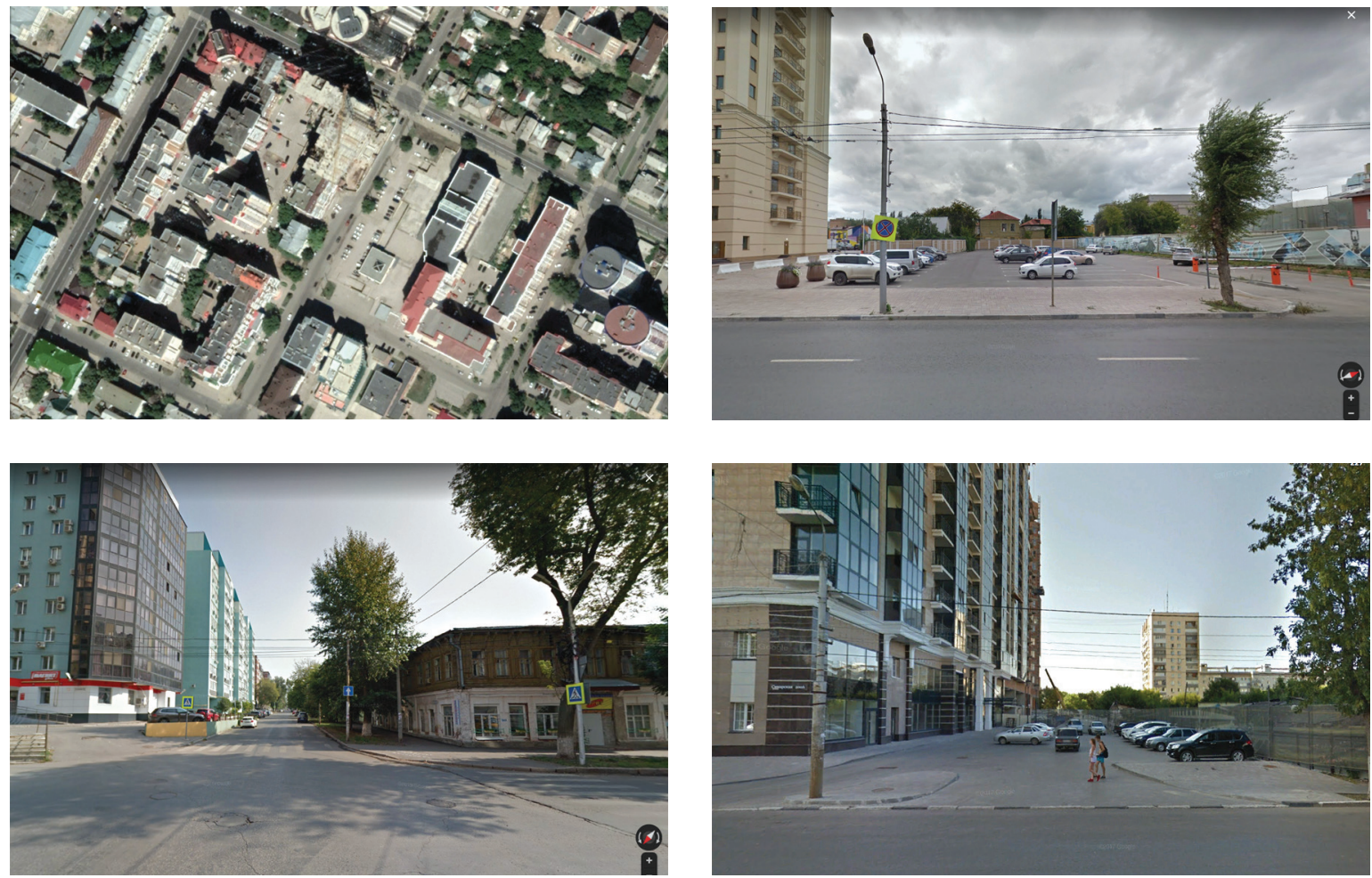

(c) Google 2020

Рис. 8. Преобразование исторической среды Самары

Другая важная особенность, отличающая российские города и регионы от городов в странах со стабильными рыночными системами, - ограниченное использование инструментов заемного финансирования. Отечественный рынок муниципальных и субфедеральных облигаций совершенно не развит [Ларина, 2016]. В структуре совокупного долга на региональном уровне на ценные бумаги приходится $25 \%$ объема, на муниципальном уровне - всего $6 \%{ }^{14}$ (за счет четырех городов: Новосибирска, Томска, Волгограда и Нижнего Новгорода).

Во-первых, это объясняется тем, что сегодня в России фактически не существует того типа инвесторов, который традиционно вкладывается в региональные и муниципальные облигации - институциональные инвесторы сильно ограничены. Сбережения населения также хранятся преимущественно на банковских депозитах [Лосев, 2015]. Во-вторых, в возможности использовать долговые инструменты муниципалитеты сильно ограничены бюджетным законодательством. Предельный объем долга устанавливается в зависимости от объема собственных доходов бюджета. Рынок инфраструктурных облигаций, которые, по сути, предназначены для снижения рисков и привлечения инвестиций в небольшие муниципальные проекты, также находится в зачаточном состоянии [Стюарт, 2017].

При этом инструменты государственно- и муниципально-частного партнерства достаточно активно используются, а законодательство в сфере ГЧП позволяет с его помощью реализовывать проекты по ревитализации объектов культурного наследия (ОКН). Всего на январь 2019 г. в стадии реализации находилось 55 проектов ГЧП в отношении ОКН, в основном это льготная аренда по программе «рубль за метр» ${ }^{15}$. Что касается инвестиций в инфраструктуру в целом рынок ГЧП активно растет, постепенно повышается сложность проектов.

Показателен пример самарского проекта «5 кварталов». Масштабный проект реновации исторической среды предполагал формат публично-частного партнерства в широком смысле, нетрадиционном для российской практики. Он был достаточно глубоко проработан с точки зрения управленческих механизмов и распределения ролей: региональный и муниципальный бюджеты должны были финансировать затраты на расселение жителей, инженерные комму-

142019 г. Анализ авторов на основе данных Министерства финансов РФ <https://www.minfin.ru/>.

15 По данным базы данных проектов ГЧП «РОСИНФРА». 


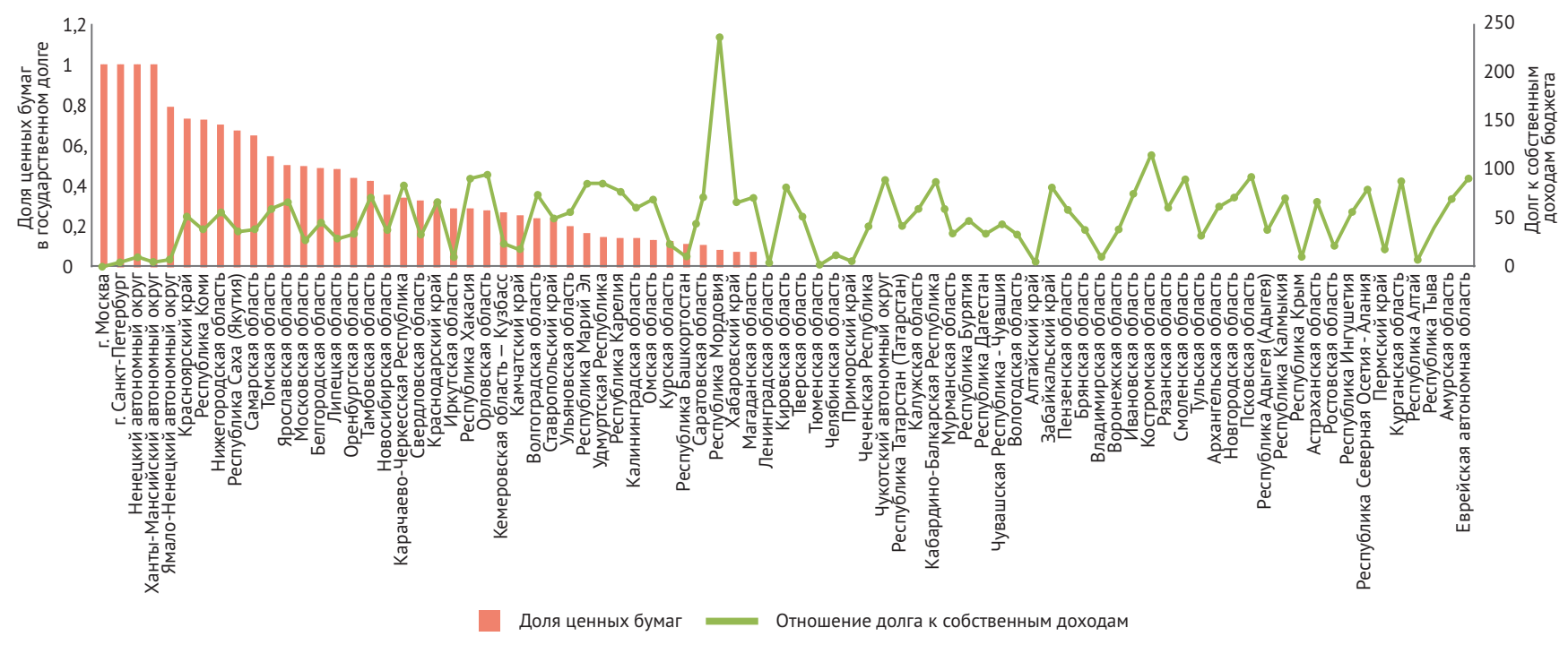

Рис. 9. Доля субфедеральных ценных бумаг в объеме регионального долга

Источник: составлено авторами на основе данных ЦБ РФ.

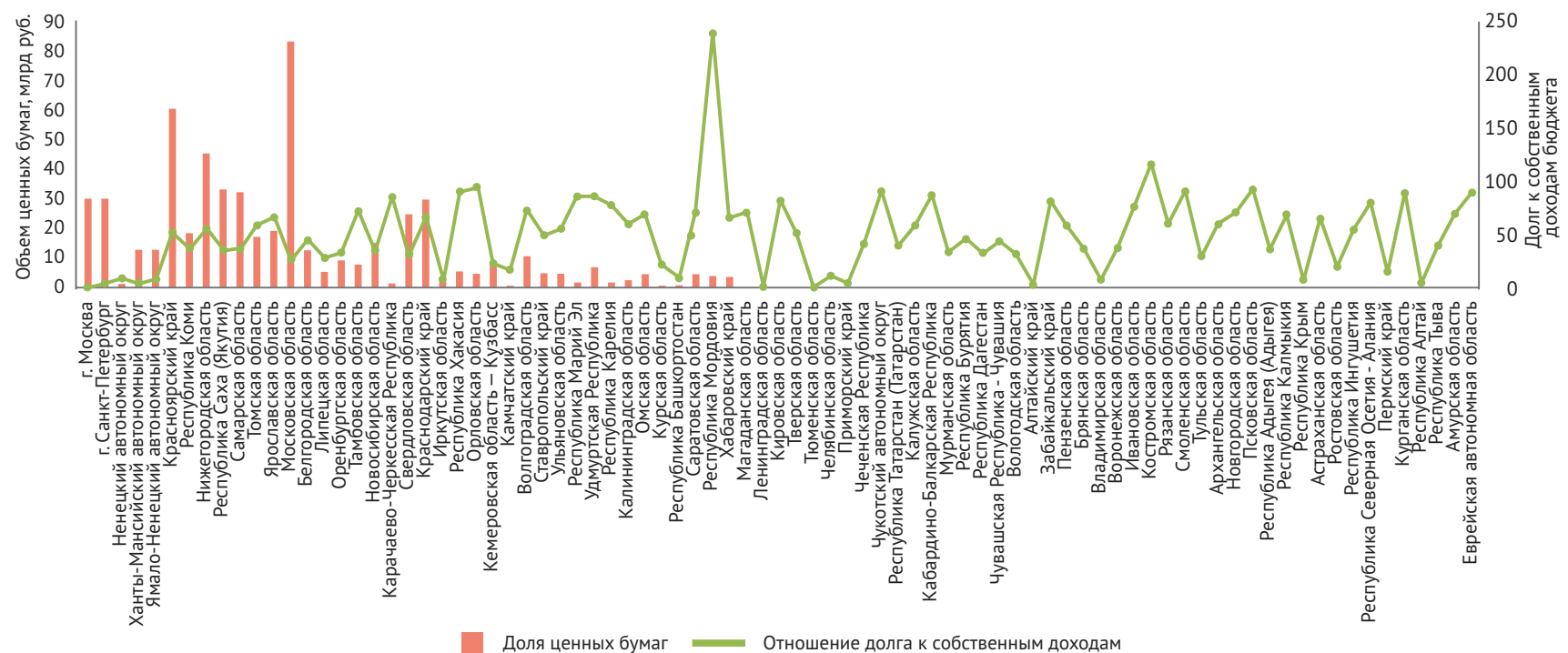

Рис. 10. Объем регионального долга в форме субфедеральных ценных бумаг

Источник: составлено авторами на основе данных ЦБ РФ.

никации и формирование лотов для частных инвесторов. Для финансирования части затрат региональные власти выпустили облигационный заём. Однако затянувшийся процесс внесения изменений в документы градостроительного зонирования, изменение планов власти, протесты жителей и общественности не позволили начать реализацию проекта в срок. Проценты по выпущенным облигациям нужно было выплачивать, а деньги так и не начали использовать. В итоге было принято решение о досрочном погашении займа, а реализация проекта фактически остановилась на неопределенный срок. 


\section{Заключение}

Выработка подходов к развитию исторических территорий должна базироваться на понимании их полезных характеристик. Историческая среда обладает свойствами, которые делают возможным гармоничное сочетание в этой среде разных функций, появление качественного жилья, развитие стрит-ритейла, привлечение туристического потока. В этих свойствах состоит уникальность исторической застройки в городе, и потому их следует рассматривать не только как набор параметрических ограничений при регулировании, но и как пространственные предпосылки для развития.

Зарубежный опыт развития исторических территорий показывает, что роль координатора традиционно берет на себя публичная власть. Она определяет цели и приоритеты развития, оценивая эффекты в долгосрочной перспективе. Она может использовать инструменты как прямого финансирования, так и косвенного стимулирования. Последние направлены на вовлечение в процесс ревитализации частных игроков: горожан, девелоперов, локального бизнеса и некоммерческих организаций. Власти могут компенсировать разницу между частными выгодами и издержками проектов с положительными общественными эффектами с помощью, например, создания инфраструктуры и предоставления льгот.

Для финансирования проектов развития наравне с собственными средствами города активно используют заемное финансирование. Привлечение частного капитала в сложные долгосрочные проекты развития происходит за счет различных форм публично-частного партнерства. Перераспределение рисков между публичной и частной стороной позволяет в определенной мере нивелировать недостатки существующей институциональной среды на локальном уровне и тем самым сделать проекты более привлекательными для инвесторов. Использование более сложных механизмов финансирования приводит к необходимости внимательного отношения к прогнозированию эффектов (прямых и косвенных, бюджетных).

Практический опыт зарубежных городов и оптика новой институциональной теории позволяют отметить высокое влияние институциональной среды на развитие территорий. Постсоциалистические города сегодня сталкиваются с рядом проблем, связанных с тем, что базовые институты находятся в стадии трансформации. Административно-командная экономика и характерная система государственного управления, в течение долгого времени существовавшие в этих странах, привели к некоторым следствиям, затрудняющим вовлечение в процесс развития исторических центров широкого круга игроков: низкий уровень гражданского участия, слабое развитие финансовых рынков и инструментов. В некоторых странах государство сегодня предпринимает попытки решения этих проблем.

Анализ процессов, которые происходят сегодня в историческом центре Самары, показывает, что они ведут к исчерпанию полезных свойств среды. Историческая застройка, в том числе и объекты культурного наследия, ветшают и подлежат сносу, а новая застройка нарушает сложившиеся параметры. Эти тенденции - результат несовершенства институциональной среды и отсутствия последовательного подхода к управлению развитием. В существующих условиях как у частных игроков, так и у городских администраций недостаточно стимулов для развития территорий с расчетом на долгосрочную перспективу.

Сегодня в российском законодательстве в сфере охраны культурного наследия появляются инструменты, позволяющие работать не только с отдельными объектами, но и с территориями. Применение статуса исторического поселения позволяет гармонизировать сложившуюся нормативно-правовую базу и регулировать объемно-пространственные характеристики среды. Однако само по себе такое регулирование имеет ограничительный характер и его недостаточно, когда речь идет о регенерации исторических центров. Переход от их консервации к их развитию возможен только при грамотном сочетании политик регулирования и стимулирования.

\section{Источники}

Бюджетный кодекс Российской Федерации от 31 июля 1998 г. N 145-Ф3, ст. 61.2.

Гончарова Е. (2014) Регулирование предельных параметров застройки в исторической городской среде: интеграция подхода Form Based Code в российскую систему регулирования застройки: магистерская диссертация. Высшая школа урбанистики НИУ ВШЭ. 
Гудзь Т., Карасельникова И., Косолапов Н. (2020) Практика применения Правил землепользования и застройки. Последствия ограничения высотности застройки в Центральном планировочном районе г. Перми. Тезисы к докладу в рамках XXI Апрельской международной научной конференции по проблемам развития экономики и общества. НИУ ВШЭ.

Де Сото Э. (2001) Загадка капитала. Почему капитал торжествует на Западе и терпит поражение во всем остальном мире / пер. с англ. М.: Олимп-бизнес.

Институт Города Самара, Кафедра ИП СГАСУ, Высшая школа урбанистики (2016). Концепция Стратегии пространственного развития исторической части Самары.

Карасельникова И.В. (2017) Интеграция механизмов партисипаторного бюджетирования в практики управления территориальным развитием: курсовая работа. Высшая школа урбанистики НИУ ВШЭ.

Карасельникова И.В. (2018) Развитие исторических территорий крупнейших городов: подходы к оценке потенциальных экономических эффектов: выпускная квалификационная работа. НИУ ВШЭ.

Карта пожаров в Самаре // Самара для людей. Режим доступа: https://www.google.com/maps/d/u/0/viewer?hl =ru\&mid=1s6EuKA9MbgM0FSvRMvH_GEXsZf8\&ll=53.17875982217774\%2C50.12701024577427\&z=13 (дата обращения: 10.04.2019).

КБ «Стрелка» (2017). Богатство и самостоятельность: что делает бюджет города устойчивым. Бюджеты региональных столиц 2013-2015 гг. Москва.

Ларина О., Морыженкова Н. (2016) Субфедеральные и муниципальные заимствования в России: содержание, источники, зарубежный опыт и перспективы развития. Региональная экономика: теория и практика. № 1.

Лащенко С., Репина Е., Грозовский Б. (2018) Как регенерировать историческую среду российских городов: инструменты соучастия и регулирования // Innovative Project. T. 3. № 9.

Лосев А. (2008) Почему россияне не покупают ценные бумаги // Banki.ru. Режим доступа: http://www.banki.ru/ news/columnists/?id=7909658 (дата обращения: 17.12.2019).

Меерович М. (2008) Политическая история советского градостроительства // Проект Байкал. № 18. С. 46-49.

Меерович М. (2012) Восток и Запад. Две природы урбанизации - два пути принятия решений // Archi.ru. Режим доступа: https://archi.ru/russia/42648/vostok-i-zapad-dve-prirody-urbanizacii-dva-puti-prinyatiya-reshenii (дата обращения: 10.04.2019).

Метод бесконфликтной реконструкции исторического квартала. «79 квартал» // Другой город. Режим доступа: http://drugoigorod.ru/ostozhenka/ (дата обращения: 10.04.2019).

Мониторинг Института развития строительной отрасли (ИРСО) (2018). 18 декабря // Строительная газета. Режим доступа: https://www.stroygaz.ru/publication/item/samarskiy-perenos/ (дата обращения: 10.04.2019).

НортД.(1997) Институты, институциональные изменения и функционирование экономики / Фонд экономической книги «НАЧАЛА» / пер. с англ. Москва.

Полтерович В. (2001) Трансплантация экономических институтов // Экономическая наука современной России. № 3.

Пять кварталов Самары открыты для инвесторов // RS 63.ru. Режим доступа: https://rs63.ru/rs-invest/662257/ (дата обращения: 10.04.2019).

Разница в весе // Строительная газета. Режим доступа: https://www.minstroyrf.ru/press/stroitelnaya-gazetabolshie-banki-ne-zamechayut-malenkikh-zastroyshchikov/ (дата обращения: 17.12.2019).

Реформа ЖКХ // Официальный сайт «Реформа ЖКХ». Режим доступа: https://www.reformagkh.ru/opendata (дата обращения: 17.12.2019).

Решение Пермской городской думы от 27 августа 2017 г. № 171 «О внесении изменений в Правила землепользования и застройки города Перми, утвержденные решением Пермской городской думы от 26 июня 2007 г. N 143».

Рипкема Д. (2006) Экономика исторического наследия. М.: Билдинг Медиа Груп.

СамГТУ (2019). НИР Разработка проекта предмета охраны, границ территории,требований к градостроительным регламентам в указанных границах в целях включения городского округа Самара в перечень исторических поселений.

Стадников В.Э. (2019) Исторические территории. Нормативные и ненормативные подходы к обновлению (Наrd \& Soft) // Архитектон: известия вузов. № 2 (66).

Стадников В.Э. (2010) Метод бесконфликтной реновации типового регулярного квартала исторического российского города // Архитектон: известия вузов. № 4 (32).

Строительство с обременением (2017) // Коммерсантъ. 21 марта. Режим доступа: https://www.kommersant.ru/ doc/3247737 (дата обращения: 17.12.2019). 
Стюарт Е. (2017) Иллюзия инфраструктурных облигаций. Почему фокус не удался? // Forbes. Режим доступа: https://www.forbes.ru/finansy-i-investicii/349401-illyuziya-infrastrukturnyh-obligaciy-pochemu-fokus-neudalsya (дата обращения: 17.12.2019).

Указ Президента Российской Федерации от 25 апреля 2019 г. № 193.

Фрейнкман Л.М., Дашкеев В.В., Муфтяхетдинова М.Р. (2009) Анализ институциональной динамики в странах с переходной экономикой. М.: ИЭПП.

Хронология: что происходило с Арскими казармами // Инде. Режим доступа: https://inde.io/article/20261hronologiya-chto-proishodilo-s-arskimi-kazarmami-v-poslednie-10-let (дата обращения: 17.12.2019).

Acemoglu D., Robinson J. (2012) Why Nations Fail: The Origins of Power, Prosperity and Poverty (1st). 1st ed. N. Y.: Crown.

Ahlfedlt G., Pietrostefani E. (2017) Demystifying Compact Urban Growth: Evidence from 300 Studies from Across the World // Coalition for Urban Transitions. London; Washington, DC.

Alchian A.A., Demsetz H. (1973) The property right paradigm // The Journal of Economic History. Vol. 33. No. 1.

Araldi A. (2019) Retail Distribution and Urban Form. Street-based Models for the French Riviera: Phd Dissertation in Geography. Université Côte d’Azur.

Bobkova E. et al. (2019) Structure of Plot Systems and Economic Activity in Cities: Linking Plot Types to Retail and Food Services in London, Amsterdam and Stockholm // Urban Science. Vol. 3 (3). P. 66.

Chau K.W., Choy L.H.T., Lee H.Y. (2018) Institutional arrangements for urban conservation // Journal of Housing and the Built Environment. Vol. 33. P. 455-463

Coase R.H. et al. (1960) The problem of social cost // Journal of Law and Economics. Vol. 3. No. 1.

Conserve and Revitalise Hong Kong Heritage. Consultancy Study on the Heritage Conservation Regimes in Other Jurisdictions. 2014. Режим доступа: https://www.heritage.gov.hk/en/doc/Policy_review_20140416.pdf (дата обращения: 12.04.2019).

EPA “Attracting Infill Development in Distressed Communities: 30 Strategies”. 2015.

Feldman M., Hadjimichael T., Kemeny T., Lanahan L. The logic of economic development: a definition and model for investment // Environment and Planning C: Government and Policy. 2015.

Hardin G. (1968) The Tragedy of the Commons // Science. 162. P. 1243-1248.

Heritage as Common(s) - Commons as Heritage (2015) / H. Benesch, U. Holmberg (eds). Makadam Publishers, Gothenburg \& Stockholm, Sweden.

Hlaváček P., Raška P., Balej M. (2016) Regeneration Projects in Central and Eastern European Post-Communist Cities: Current Trends and Community Needs // Habitat International. No. 56.

Ho P. (2019) Institutional Function Versus Form: The Evolutionary Credibility of Land, Housing and Natural Resources // Land Use Policy. Vol. 75. P. 642-650.

Holvandus J., Leetmaa K. (2016) The Views of Neighbourhood Associations on Collaborative Urban Governance in Tallinn, Estonia. plaNext - next generation planning. 3. P. 49-66.

Hong Kong Urban Renewal Strategy (2011). Режим доступа: https://www.ura.org.hk/en/about-ura/ura-ordinanceand-urban-renewal-strategy (дата обращения: 12.04.2019).

Jacobs J. (1961) The Death and Life of Great American Cities. N. Y.: Random House.

Kim J. (2016) Handbook on Urban Infrastructure Finance. New Cities Foundation. Режим доступа: http://bit.ly/ NCFUrbanFinance (дата обращения: 12.04.2019).

Kropf K. (2009) Aspects of Urban Form. Urban Morphology 13 (2). P. 105-120.

Manson R. (2005) Economics of Historic Preservation: A Guide and Review of the Literature. Washington: Brookings Institution.

Marcus L. (2010) Spatial Capital: A proposal for an Extension of Space Syntax into a More General Urban Morphology // The Journal of Space Syntax. P. 30-40.

Marcus L. (2017) The theoretical underpinnings for a theory of spatial capital - The 11th international space syntax symposium.

Meeks S., Murphy K. (2016) The Past and Future City: How Historic Preservation Is Reviving America's Communities. Washington, DC: Island Press.

National Trust for Historic Preservation. Rebuilding Community: A Best Practices Toolkit for Historic Preservation and Redevelopment (2002). Режим доступа: https://community-wealth.org/sites/clone.community-wealth.org/files/ downloads/tool-natl-trust-hist-prsrv.pdf (дата обращения: 12.04.2019).

North D.C., Thomas R.P. (1973) The rise of the western world: A new economic history. Cambridge University Press. North D.C. (1990) Institutions, Institutional Change and Economic Performance. Cambridge University Press. 
Nutt N., Hiob M., Nurme S., Salmistu S. (2013) Gentrification in a Post-Socialist Town: The Case of the Supilinn District, Tartu, Estonia // Transylvanian Review of Administrative Sciences. 9 (SI). P. 109-123.

Older, Smaller, Better: Measuring how the character of buildings and blocks influences urban vitality (2014). National Trust for Historic Preservation.

Oliveira V. (ed.) (2018) Teaching Urban Morphology. The Urban Book Series.

Ostrom E. (1990) Governing the commons: The evolution of institutions for collective action. N. Y.: Cambridge University Press.

Ostrom E. (2005) Understanding Institutional Diversity, Princeton, NJ: Princeton University Press.

Principles // New Urbanism. Режим доступа: http://www.newurbanism.org/newurbanism/principles.html (дата обращения: 15.01.2019).

Regenerating Urban Land: A Practitioner's Guide to Leveraging Private Investment (2016) / R. Amirtahmasebi, M. Orloff, S. Wahba, A. Altman. World Bank: Urban Development.

SMOG. Spatial Morphology Group. Режим доступа: https://www.smog.chalmers.se (дата обращения: 02.02.2018).

Sýkora L., Bouzarovski S. (2012) Multiple Transformations: Conceptualising the Post-communist Urban Transition. Urban Studies. Vol. 49 (1). P. $43-60$.

The Infill and Redevelopment Code Handbook (1999). Oregon Department of Land Conservation and Development. Режим доступа: https://www.oregon.gov/lcd/Publications/Infill_Redevelopment_CodeHandbook_1999. pdf (дата обращения: 02.02.2018).

UN-Habitat for the Sustainable Development Goals. Режим доступа: https://unhabitat.org/un-habitat-for-thesustainable-development-goals/ (дата обращения: 02.02.2018).

UNESCO (2008). "Historic districts for all: a social and human approach for sustainable revitalization; brochure designed for local authorities”. Режим доступа: https://unesdoc.unesco.org/ark:/48223/pf0000158331 (дата обращения: 02.02.2018).

UNESCO (2015). "Policy Document for the Integration of a Sustainable Development Perspective into the Processes of the World Heritage Convention”. Режим доступа: https://whc.unesco.org/en/sustainabledevelopment/ (дата обращения: 02.02.2018). 


\section{IRINA KARASELNIKOVA, VITALY STADNIKOV \\ TOWARDS THE SUSTAINABLE DEVELOPMENT OF HISTORICAL CENTERS}

Irina V. Karaselnikova, Expert, Vysokovsky Graduate School of Urbanism, Faculty of Urban and Regional Development, HSE University; 13 bldg. 4 Myasnitskaya Ulitsa, Moscow, 101000, Russian Federation, tel.: +7 (937) 611-75-70

E-mail: ikaraselnikova@hse.ru

Vitaly E. Stadnikov, PhD, Associate Professor of Vysokovsky Graduate School of Urbanism, Faculty of Urban and Regional Development, HSE University; 13 bldg. 4 Myasnitskaya Ulitsa, Moscow, 101000, Russian Federation, tel.: +7 (926) 398-63-26

E-mail: stadnikov@bk.ru

\section{Abstract}

Excluded from the urban policy discourse during Soviet period, historical centers of Russian cities are of interest to private developers today. The current development of these territories leads to the loss of valuable morphological characteristics which have been formed evolutionarily: lot configuration and size, building height and density, etc.

The attitudes of public authorities towards the maintenance of historical territories today mainly comes down to the preservation of listed heritage buildings. The status of historical settlements is a new tool in Russian heritage preservation policies. It allows the regulation of infill development parameters in historical areas and thereby protects the historic environment as an entity. Heritage preservation restrictions, however, are considered an obstacle for urban development since the logic of conservation is opposed to that of development. Public authorities, private developers and local residents have little to no resources and incentives to develop territories in accordance with the imposed restrictions.

This article argues that despite the strengths of these tools, it is not enough when territory revitalization is the goal. Existing regulations should be expanded by a set of incentive measures to stimulate the revitalization of historical urban cores and turn heritage into a capitalized asset.

The first part of the article is devoted to the theoretical underpinnings for elaborating an approach to the revitalization process. The authors appeal to urban morphology theory in order to determine the potential of historical environments. The second part is devoted to a review of best practices in the revitalization of historical centers. Third part of the article gives an overview of the current development practices of various stakeholders in the existing institutional context. The case of the historical center of Samara is used to illustrate the common phenomena.

Institutional economics is used to review the system of incentives and approaches to assessing the effects and to evaluate the contribution of various factors to the investment attractiveness of the territory and the development process as a whole.

Key words: historical preservation; historical revitalization; urban economics; urban morphology; sustainable development

Citation: Karaselnikova I., Stadnikov V. (2018) Towards the Sustainable Development of Historical Centers. Urban Studies and Practices, vol. 3, no 4,pp. 108-132 (in Russian).

DOI: https://doi.org/10.17323/usp342018108-132 


\section{References}

Acemoglu D., Robinson J. (2012) Why Nations Fail: The Origins of Power, Prosperity and Poverty (1st). 1st ed. New York: Crown.

Ahlfedlt G., Pietrostefani E. (2017) Demystifying Compact Urban Growth: Evidence from 300 Studies from Across the World. Coalition for Urban Transitions, London and Washington, DC.

Alchian A.A., Demsetz H. (1973) The property right paradigm. The Journal of Economic History, vol. 33, no 1.

Araldi A. (2019) Retail Distribution and Urban Form. Street-based Models for the French Riviera: Phd Dissertation in Geography. Université Côte d'Azur.

Byudzhetnyj kodeks Rossijskoj Federacii ot 31.07.1998 N 145-FZ, st. 61.2 [Budget code of the Russian Federation]. (in Russian)

Bobkova E. et al. (2019) Structure of Plot Systems and Economic Activity in Cities: Linking Plot Types to Retail and Food Services in London, Amsterdam and Stockholm. Urban Science, vol. 3 (3), p. 66.

Chau K.W., Choy L.H.T., Lee H.Y. (2018) Institutional arrangements for urban conservation. Journal of Housing and the Built Environment, vol. 33, pp. 455-463.

Coase R.H. et al. (1960) The problem of social cost. Journal of Law and Economics, vol. 3, no 1.

Conserve and Revitalise Hong Kong Heritage (2014). Consultancy Study on the Heritage Conservation Regimes in Other Jurisdictions. Available at: https://www.heritage.gov.hk/en/doc/Policy_review_20140416.pdf (accessed 12.04.2020).

De Soto J. (2001) Zagadka kapitala. Pochemu kapital torzhestvuet na Zapade i terpit porazhenie vo vsem ostal'nom mire [The Mystery of Capital: Why Capitalism Triumphs in the West and Fails Everywhere Else]. Moscow: Olimp-biznes. (in Russian)

EPA (2015). Attracting Infill Development in Distressed Communities: 30 Strategies.

Feldman M. et al. (2015) The logic of economic development: a definition and model for investment. Environment and Planning C: Government and Policy.

Frejnkman L.M., Dashkeev V.V., Muftjahetdinova M.R. (2009) Analiz institucional'noj dinamiki v stranah s perehodnoj jekonomikoj [Analysis of Institutional Dynamics in the Economies in Transition]. Moskva. IEP. (in Russian)

Goncharova E. (2014) Regulirovanie predel'nyh parametrov zastrojki v istoricheskoj gorodskoj srede: integracija podhoda Form Based Code v rossijskuju sistemu regulirovanija zastrojki [Regulation of Building limit Parameters in a Historical Urban Environment: Integration of the Form Based Code Approach into the Russian Building Regulation System]. Master Thesis. HSE University. (in Russian)

Gudz' T., Karaselnikova I., Kosolapov N. (2020) Praktika primenenija Pravil zemlepol'zovanija i zastrojki. Posledstvija ogranichenija vysotnosti zastrojki v Central'nom planirovochnom rajone g. Permi [Practice of Land Use Regulations Enforcement. The Consequences of Imposing Height Restrictions on Perm Central Planning Area]. XXI April International Academic Conference on Economic and Social Development. HSE University. (in Russian)

Hardin G. (1968) The Tragedy of the Commons. Science, 162, pp. 1243-1248.

Heritage as Common(s) - Commons as Heritage (2015) / H. Benesch, F. Hammami, I.M. Holmberg, E. Uzer (eds). Makadam Publishers, Gothenburg \& Stockholm, Sweden.

Hlaváček P., Raška P., Balej M. (2016) Regeneration Projects in Central and Eastern European Post-Communist Cities: Current Trends and Community Needs. Habitat International, 56.

Holvandus J., Leetmaa K. (2016) The Views of Neighbourhood Associations on Collaborative Urban Governance in Tallinn, Estonia. plaNext - next generation planning, 3, pp. 49-66.

Hong Kong Urban Renewal Strategy (2011). Available at: https://www.ura.org.hk/en/about-ura/ura-ordinance-andurban-renewal-strategy (accessed 12.04.2019).

Ho P. (2019) Institutional Function Versus Form: The Evolutionary Credibility of Land, Housing and Natural Resources. Land Use Policy, 75, pp. 642-650.

Hronologija: chto proishodilo s Arskimi kazarmami [Chronology: what happened to the Arsk barracks]. Inde. Available at: https://inde.io/article/20261-hronologiya-chto-proishodilo-s-arskimi-kazarmami-v-poslednie-10let (accessed 17.12. 2019). (in Russian)

Institut Goroda Samara, Kafedra IP SGASU, Vysshaja shkola urbanistiki (2016). Koncepcija Strategii Prostranstvennogo razvitija istoricheskoj chasti Samary [The Concept of Spatial Development of the Historical Center of Samara]. (in Russian)

Jacobs J. (1961) The Death and Life of Great American Cities. New York: Random House. 
Karaselnikova I. (2017) Integracija mehanizmov partisipatornogo bjudzhetirovanija v praktiki upravlenija territorial'nym razvitiem [Integration of the Participatory Budgeting Mechanisms to the Territory Development Process]. Thesis. HSE University. (in Russian)

Karaselnikova I. (2018) Razvitie istoricheskih territorij krupnejshih gorodov: podhody k ocenke potencial'nyh jekonomicheskih jeffektov [Revitalization of Historic Urban Core in Major Cities: Approaches to Evaluation of Potential Economic Effects]. Master Thesis. HSE University. (in Russian)

Karta pozharov v Samare [Samara fire map]. Samara dlja ljudej. Available at: https://www.google.com/maps/d/u/0/vie wer?hl=ru\&mid=1s6EuKA9MbgMOFSvRMvH_GEXsZf\&\&ll=53.17875982217774\%2C50.12701024577427\&z=13 (accessed 10.04.2019). (in Russian)

Kim J. (2016) Handbook on Urban Infrastructure Finance. New Cities Foundation. Available at: http://bit.ly/ NCFUrbanFinance (accessed 12.04.2019).

KB Strelka (2017). Bogatstvo i samostojatel'nost': chto delaet bjudzhet goroda ustojchivym. Bjudzhety regional'nyh stolic 2013-2015 gg [Wealth and independence: what makes the city budget sustainable]. (in Russian)

Kropf K. (2009) Aspects of Urban Form. Urban Morphology, 13 (2), pp. 105-120.

Larina O., Moryzhenkova N. (2016) Subfederal'nye i municipal'nye zaimstvovanija v Rossii: soderzhanie, istochniki, zarubezhnyj opyt i perspektivy razvitija [Russian Sub-national Debt: the Content, Sources, Foreign Experience, and Perspectives]. Regional'naja jekonomika: teorija i praktika [Regional Economics. Theory and Practice], no 1. (in Russian)

Lashhenko S., Repina E., Grozovskij B. (2018) Kak regenerirovat' istoricheskuju sredu rossijskih gorodov: instrumenty souchastija i regulirovanija [How to regenerate the historical environment of russian cities: participation and regulation tools]. Innovative Project, vol. 3, no 9. (in Russian)

Losev A. Pochemu rossijane ne pokupajut cennye bumagi [Why Russians do not buy securities]. Banki.ru. Available at: http://www.banki.ru/news/columnists/?id=7909658 (accessed 17.12.2019). (in Russian)

Manson R. (2005) Economics of Historic Preservation: A Guide and Review of the Literature. Washington: Brookings Institution.

Marcus L. (2010) Spatial Capital: A proposal for an Extension of Space Syntax into a More General Urban Morphology. The Journal of Space Syntax, pp. 30-40.

Marcus L. (2017) The theoretical underpinnings for a theory of spatial capital - The 11th international space syntax symposium.

Meeks S., Murphy K. (2016) The Past and Future City: How Historic Preservation Is Reviving America's Communities. Washington, DC: Island Press.

Meerovich M. (2008) Politicheskaja istorija sovetskogo gradostroitel'stva [Political History of Soviet Urban Planning]. Project Bajkal, no 18, pp. 46-49. (in Russian)

Meerovich M. (2012) Vostok i Zapad. Dve prirody urbanizacii - dva puti prinjatija reshenij [East and West. The Two Natures of Urbanization - Two Ways of Making Decisions]. Archi.ru. Available at: https://archi.ru/russia/42648/ vostok-i-zapad-dve-prirody-urbanizacii-dva-puti-prinyatiya-reshenii (accessed 10.04.2019). (in Russian)

Metod beskonfliktnoj rekonstrukcii istoricheskogo kvartala. "79 kvartal" [Conflict -free renovation of a typical regular quarter. "79 quarter"]. Drugoj gorod. Available at: http://drugoigorod.ru/ostozhenka/ (accessed 10.04. 2019). (in Russian)

Monitoring Instituta razvitija stroitel'noj otrasli (IRSO) [Monitoring of the Institute for the Development of the Construction Industry] 18.12.2018. Stroitel'naja gazeta. Available at: https://www.stroygaz.ru/publication/item/ samarskiy-perenos/ (accessed 10.04.2019). (in Russian)

National Trust for Historic Preservation. Rebuilding Community: A Best Practices Toolkit for Historic Preservation and Redevelopment (2002). Available at: https://community-wealth.org/sites/clone.community-wealth.org/files/ downloads/tool-natl-trust-hist-prsrv.pdf (accessed 12.04. 2019).

Nort D. (1997) Instituty, institucional'nye izmenenija i funkcionirovanie jekonomiki [Institutions, Institutional Change and Economic Performance]. Fond jekonomicheskoj knigi “NAChALA”. Moscow. (in Russian)

North D.C., Thomas R.P. (1973) The Rise of the Western World: A New Economic History. Cambridge: Cambridge University Press.

North D.C. (1990) Institutions, Institutional Change and Economic Performance. Cambridge: Cambridge University Press.

Nutt N., Hiob M., Nurme S., Salmistu S. (2013) Gentrification in a Post-Socialist Town: The Case of the Supilinn District, Tartu, Estonia. Transylvanian Review of Administrative Sciences, 9 (SI), pp. 109-123.

Older, Smaller, Better: Measuring how the character of buildings and blocks influences urban vitality (2014). National trust for historic preservation. 
Oliveira V. (ed.) (2018) Teaching Urban Morphology. The Urban Book Series.

Ostrom E. (1990) Governing the Commons: The Evolution of Institutions for Collective Action. New York: Cambridge University Press.

Ostrom E. (2005) Understanding Institutional Diversity. Princeton, NJ: Princeton University Press.

Polterovich V. (2001) Transplantacija jekonomicheskih institutov [Transplantation of economic institutions]. Jekonomicheskaja nauka sovremennoj Rossii [Economics of Contemporary Russia], no 3. (in Russian)

Principles. New Urbanism. Available at: http://www.newurbanism.org/newurbanism/principles.html (accessed 15.01.2019).

Pyat' kvartalov Samary otkryty dlja investorov [Five quarters of Samara are open to investors]. RS 63.ru. Available at: https://rs63.ru/rs-invest/662257/ (accessed 10.04.2019). (in Russian)

Raznica v vese [Weight difference]. Stroitel'naja gazeta. Available at: https://www.minstroyrf.ru/press/stroitelnayagazeta-bolshie-banki-ne-zamechayut-malenkikh-zastroyshchikov/ (accessed 17.12. 2019). (in Russian)

Regenerating Urban Land: A Practitioner's Guide to Leveraging Private Investment / Amirtahmasebi R., Orloff M., Wahba S., Altman A. World Bank. Urban Development. 2016.

Reshenie Permskoj gorodskoj Dumy ot 27.08.2019 № 171 “O vnesenii izmenenij v Pravila zemlepol'zovanija i zastrojki goroda Permi, utverzhdennye resheniem Permskoj gorodskoj Dumy ot 26.06.2007 N 143” [Decision of the Perm City Council of August 27, 2019 No. 171 "On amendments to the Rules for land use and development of the city of Perm, approved by the decision of the Perm City Council of June 26, 2007 No. 143"]. (in Russian)

Rich M.J., Stoker R.P. (2014) Collaborative Governance for Urban Revitalization: Lessons from Empowerment Zones. Cornell University Press.

Ripkema D. (2006) Jekonomika istoricheskogo nasledija [The Economics of Historic Preservation]. Moscow: Bilding Media Grup. ARX. (in Russian)

SamGTU (2019). NIR Razrabotka proekta predmeta ohrany, granic territorii, trebovanij k gradostroitel'nym reglamentam $v$ ukazannyh granicah $v$ celjah vkljuchenija gorodskogo okruga Samara v perechen' istoricheskih poselenij [Samara Historical Settelment Project Research]. (in Russian)

SMOG. Spatial Morphology Group. Available at: https://www.smog.chalmers.se (accessed 02.02.2018).

Stadnikov V.E. (2019) Istoricheskie territorii. Normativnye i nenormativnye podhody k obnovleniju (Hard \& Soft) [Historical Areas. Normative and Non-normative Approacges to Renovation]. Arhitekton: izvestija vuzov [Architecton: Proceeding of Higher Education], no 2 (66). (in Russian)

Stadnikov V.E. (2010) Metod beskonfliktnoj renovacii tipovogo reguljarnogo kvartala istoricheskogo rossijskogo goroda [Conflict -free renovation of a typical regular quarter of historical Russian city]. Arhitekton: izvestija vuzov [Architecton: Proceeding of Higher Education], no 4 (32). (in Russian)

Stroitel'stvo s obremeneniem [Encumbered Construction]. Kommersant. Available at: https://www.kommersant.ru/ doc/3247737 (accessed 17.12.2019). (in Russian)

Stjuart E. (2017) Illjuzija infrastrukturnyh obligacij. Pochemu fokus ne udalsja? [The Illusion of Infrastructure Bonds. Why the Trick Failed?]. Forbes. Available at: https://www.forbes.ru/finansy-i-investicii/349401-illyuziyainfrastrukturnyh-obligaciy-pochemu-fokus-ne-udalsya (accessed 17.12. 2019). (in Russian)

Sýkora L., Bouzarovski S. (2012) Multiple Transformations: Conceptualising the Post-communist Urban Transition. Urban Studies, vol. 49 (1), pp. 43-60.

The Infill and Redevelopment Code Handbook. Oregon Department of Land Conservation and Development (1999). Available at: https://www.oregon.gov/lcd/Publications/Infill_Redevelopment_CodeHandbook_1999.pdf (accessed 02.02.2018).

Ukaz Prezidenta Rossijskoj Federacii [Presidential Executive Order] of 25.04.2019 № 193. (in Russian)

UN-Habitat for the Sustainable Development Goals. Available at: https://unhabitat.org/un-habitat-for-the-sustainabledevelopment-goals/ (accessed 02.02.2018).

UNESCO (2008) Historic districts for all: a social and human approach for sustainable revitalization; brochure designed for local authorities. Available at: https://unesdoc.unesco.org/ark:/48223/pf0000158331 (accessed 02.02.2018).

UNESCO (2015). Policy Document for the Integration of a Sustainable Development Perspective into the Processes of the World Heritage Convention. Available at: https://whc.unesco.org/en/sustainabledevelopment/ (accessed 02.02.2018). 